\title{
Do the SEC Whistleblower Provisions of Dodd Frank Deter Aggressive Financial Reporting?
}

\author{
Christine Wiedman \\ University of Waterloo \\ Chunmei Zhu \\ University of Waterloo
}

November 2017

We are grateful for the research funding provided by the KPMG Professorship and the Centre for Accounting Research and Education to Christine Wiedman. We also thank Vishal Baloria, Dennis Chung, Karel Hrazdil, Kim Trottier and participants at the Simon Fraser University workshop and the 2017 Corporate Whistleblower Compliance Conference for helpful comments. 


\title{
Do the SEC Whistleblower Provisions of Dodd Frank Deter Aggressive Financial Reporting?
}

\begin{abstract}
The stated goal of the 2011 SEC Whistleblower (WB) Program introduced as part of the Dodd-Frank Act was to strengthen investor protection through greater deterrence of securities law violations and more effective regulatory enforcement. While the SEC has articulated the success of the program for detecting and prosecuting violations, there is no evidence on the effect of the program in deterring violations. In this paper, we consider the deterrent effect by examining the impact of the Program on aggressive financial reporting by U.S. firms. Despite ongoing challenges, including the high number of tips received and efforts by some managers to circumvent the new rules by muzzling whistleblowers, we document a significant reduction in abnormal accruals following the introduction of the regulation. In a difference-in-differences design, we also find that reductions in aggressive reporting are significantly greater for U.S. firms than for Canadian firms. Using a sample of firms with ratings of internal reporting program quality just prior to the introduction of WB Program, we find that reductions in aggressive reporting are greater for firms with weaker internal programs. We also find that the reporting of internal control weaknesses decreased significantly in the years following the introduction of the Program. Collectively, these findings provide important evidence of significant benefits of the SEC WB Program of Dodd-Frank Act for deterring financial reporting fraud.
\end{abstract}




\section{INTRODUCTION}

In November 2010, the Securities and Exchange Commission (SEC) proposed a Whistleblower Program (WB Program) as part of the Dodd-Frank Act. The stated goal of the Program was to strengthen investor protection through greater deterrence of securities law violations and more effective and efficient regulatory enforcement on the part of the SEC. The Program was enacted in August 2011 and offers financial incentives to individuals reporting violations to the SEC. Eligible whistleblowers can receive awards ranging from $10 \%$ to $30 \%$ of monetary sanctions for voluntarily providing original information about a violation that leads to the successful enforcement of a covered action.

According to the SEC the WB Program has been a success. Former SEC Chair Mary Jo White called the program a "game changer", and in a speech the former SEC Director of Enforcement Andrew J. Ceresney discussed, “...the transformative impact that the program has had on the Agency, both in terms of the detection of illegal conduct and in moving our investigations forward quicker and through the use of fewer resources." ${ }^{1}$. In its 2016 Annual Report, the SEC announced that the Office of the Whistleblower had awarded over \$111 million to 34 whistleblowers in cases with more than $\$ 580$ million ordered in sanctions. Ceresney noted that the WB Program has been particularly helpful in three categories: corporate disclosures and financials (financial reporting fraud); Ponzi schemes and offering frauds; and, violations of the Foreign Corrupt Practices Act. Financial reporting fraud made up 22 percent of the tips received in 2016.

While the SEC has articulated the effect of the program on its enforcement efforts, there is no evidence on the effect of the program in deterring securities law violations. In particular, it is not

\footnotetext{
${ }^{1}$ A. Ceresney, Speech, “The SEC's Whistleblower Program: The Successful Early Years”, September 14, 2016. Retrieved from: https://www.sec.gov/news/speech/ceresney-sec-whistleblower-program.html.

${ }^{2}$ Major provisions of Dodd-Frank that impact the financial sector include: the Financial Stability Oversight Council, which
} 
clear whether the WB Program has reduced aggressive financial reporting, and if it has, for what companies. Baloria, Marquardt and Wiedman (2017) (hereafter BMW 2017) provide early evidence of the perceived effectiveness of the WB Program by examining investors' responses to events leading up to the enactment of the proposed regulations. They find that investors expected the new provisions to provide net benefits to investors as reflected in stock price returns, particularly for firms with weaker existing internal compliance and reporting programs. In this paper, we focus directly on the changes to aggressive financial reporting and internal controls around the introduction of the WB Program.

While much of the previous literature uses restatements to measure aggressive reporting, doing so is problematic in this context. If the SEC whistleblower rules are effective in detecting fraud, the likelihood of a company restating its financial statements as a result of an investigation should increase following the introduction of the new rules. If the rules promote greater deterrence of fraud, the number of restatements should decrease (BMW 2017). Therefore, the impact of the new regulations on restatements is ambiguous. Instead, similar to the Cohen, Dey and Lys (2008) examination of the Sarbanes Oxley Act (SOX), we use measures of abnormal accruals to capture changes in aggressive reporting. For the sample period 2006 to 2014, we find that abnormal accruals are significantly lower in the years following the introduction of the SEC WB Program than the years prior. Controlling for factors identified in prior research as affecting the measurement of accruals, we document an overall reduction in accruals of approximately 11 percent. This reduction is observed for both positive and negative accruals, with a reduction of 9 percent and 17 percent in positive and negative accruals, respectively. We also observe a significant reduction in an ex ante measure for the probability of fraud following Beneish, Lee and Nichols (2013). 
One challenge of this kind of research is attributing changes in reporting over the sample period to the introduction of the WB program and not other simultaneous changes. To address this issue we first eliminate all financial sector firms from our sample, as traditional measures of accruals are not meaningful for these firms, and because banks were simultaneously impacted by a number of provisions of the Dodd-Frank Act. ${ }^{2}$ Second, we compare changes in reporting for our general population of firms to firms in the health care sector. As health care companies were already subject to similar whistleblower provisions under the False Claims Act (FCA), they are less likely to be affected by the introduction of the SEC program. Consistent with our expectations, accruals do not decline significantly for these firms. Third, we employ a differencein-differences design to measure reductions in aggressive reporting by U.S. firms relative to Canadian firms. Here, we find that reductions in aggressive reporting are significantly greater for U.S. firms relative to Canadian firms.

As a final approach, we consider whether reductions in aggressive reporting vary by the strength of the firm's internal compliance and reporting programs. By exploiting cross-sectional differences in changes that relate specifically to our context, we can increase confidence that our results relate to the SEC Program (Leuz and Wysocki 2016). The most significant area of contention for U.S. firms with the introduction of the WB Program was the ability for whistleblowers to report directly to the SEC without being required to first report through the firm's internal reporting system implemented under SOX. Firms argued that internal systems allow companies to comply with regulations and deal with irregularities on a timely manner thereby mitigating investor harm. However, BMW (2017) report that firms lobbying against the WB Program in 2010 had weaker internal reporting systems than non-lobbying firms, and that

\footnotetext{
${ }^{2}$ Major provisions of Dodd-Frank that impact the financial sector include: the Financial Stability Oversight Council, which monitors the financial stability of financial firms deemed "too big to fail"; the Consumer Financial Protection Bureau, which seeks to prevent predatory mortgage lending; and the Volcker Rule, which restricts ways in which banks can invest.
} 
investor response to the SEC WB Program was most positive for firms with weaker programs. The positive market response for weaker firms suggests that the market anticipated net benefits for these firms.

Using a sample of 224 firms with ratings of internal reporting program quality just prior to the introduction of the SEC WB Program from BMW (2017), we examine how changes in aggressive reporting vary with internal compliance and reporting program quality. Consistent with the BMW (2017) results on perceived costs and benefits of the new program, we find that reductions in aggressive reporting are greater for firms with weaker internal reporting programs. We further consider three aspects of the internal programs - program efficacy, independence from management, and whistleblower protection. Reductions in aggressive reporting are significantly increasing in the latter two dimensions. That is, reductions in aggressive reporting are most significant for firms where, prior to the introduction of the rules, employees could not report irregularities to a group independent from management and where whistleblower protection was weak. This suggests that the benefits to the new WB Program are most prevalent for firms where systems for employee reporting of fraud were weakest at the time of its introduction.

As one mechanism for improving financial reporting is through improved internal controls, we also consider changes in internal controls around the introduction of the new rules. Controlling for other determinants of internal control weaknesses (ICWs), we find that the reporting of ICWs decreased significantly in the years following the introduction of the SEC WB Program for both Section 404 and 302 disclosures. We also consider whether firms improve their internal compliance and reporting programs. If employees at firms with weak compliance programs have greater incentives to report externally, we expect those firms will strengthen 
internal programs in the hopes of encouraging potential whistleblowers to report internally first to allow them to deal with issues on a timely and proactive basis. Using specific Section 302 disclosures that relate to internal programs, we find that weaknesses relating to a firm's internal WB Policy (including ethics hotlines) decrease significantly following the SEC rules.

We make several contributions to the literature. To our knowledge, this is the first marketwide empirical evidence on the ex post effects of the SEC WB Program. We document a reduction in aggressive reporting for U.S. firms following the WB Program, thereby providing evidence on the effect of the Program on deterring fraud. We also find that fewer firms report ICWs and fewer firms report weaknesses related specifically to their internal compliance and reporting programs. These findings provide important evidence of significant benefits of the SEC WB Program of Dodd-Frank Act for deterring financial reporting fraud and should be of interest to investors and regulators, particularly at a time when provisions of the Dodd-Frank Act are being questioned and in some cases repealed or modified. ${ }^{3}$

We also contribute to the recent literature on the role of whistleblowers in detecting fraud and the benefits of WB Programs that provide monetary incentives to whistleblowers. Call, Martin, Sharp and Wilde (2016) examine SEC and Department of Justice (DOJ) enforcement actions since SOX. They find that when a whistleblower is involved in the action, regulators are able to impose higher penalties for the firms and their employees implicated in the fraud, obtain longer prison sentences for culpable employees, and reduce the overall time to discovery. Regarding the effectiveness of regulation, Lee (2016) considers US state adoptions of the False Claims Act (FCA) which provides monetary awards to whistleblowers who bring to light fraud

\footnotetext{
${ }^{3}$ In June 2017, the Trump administration introduced plans to weaken elements of the Dodd-Frank Act including curbing the authority of the Consumer Financial Protection Bureau and exempting banks with less than $\$ 10$ billion in assets from the Volker Rule. Earlier in the month, Republicans had introduced more sweeping legislation in the House proposing to repeal 40 provisions of Dodd-Frank. While the legislation passed by a vote of 233-186, it was not expected to clear the Senate in its original form.
} 
against that state's pension fund investments. She finds that the introduction of whistleblower regulations in a given state significantly reduces ex ante estimates of accounting fraud in that state. BMW (2017) analyze investor reactions to a number of key event dates leading to the introduction of the SEC WB Program. They find that investor reaction is more positive for lobbying than non-lobbying firms, suggesting that investors expect the benefits on the new rules to exceed the costs, particularly for those firms most affected by the new rules. In this study, we find a significant reduction in aggressive reporting for publicly traded US firms following the introduction of the SEC WB provisions. Collectively, these findings underscore the important role that whistleblowers play in detecting fraud and the significant benefits of whistleblower "bounty" regulatory programs in deterring and detecting fraud.

\section{BACKGROUND AND HYPOTHESES}

\section{The SEC WB Program}

The idea of an SEC whistleblower program was first introduced in a testimony by then SEC Chair Mary Shapiro before the U.S. Senate Committee on Banking, Housing and Urban Affairs on March 26, 2009. ${ }^{4}$ In response to the financial crisis, Shapiro acknowledged the critical need for regulatory reform with a focus on enhanced investor protection and securities regulation. One element of the broad plans laid out in her testimony included “...a request for authority to compensate whistleblowers who bring us well-documented evidence of fraudulent activity." Shapiro later officially requested a WB Program in July 2009, citing criticism of the SEC's handling of the Bernard Madoff Ponzi scheme and the need for the agency to incentivize

\footnotetext{
${ }^{4}$ Testimony by Mary L. Shapiro, March 26, 2009. Retrieved from: https://www.sec.gov/news/testimony/2009/ts032609mls.htm.
} 
whistleblowers and revamp the process for evaluating the tips received. ${ }^{5}$ A detailed proposal of the plan was released on November 3, 2010 with an invitation for public comment; the Agency received over 1,000 submissions.

As reported by BMW (2017) in their analysis of comment letters to the SEC, support for the proposal was mixed. While individuals were strongly in favor of the rules, other groups including lawyers and non-investor groups were mixed and the 283 corporate respondents were unanimously negative. For corporations, the most significant point of contention was that the proposed rules did not require whistleblowers to first report misconduct through company internal compliance and reporting programs prior to reporting to the SEC. Firms' internal compliance programs were previously formalized under SOX to improve financial reporting practices. Section 406 of SOX requires companies to disclose whether the company has adopted a written Code of Ethics, which should be "designed to deter wrongdoing and to promote compliance with governmental laws, rules, and regulations; prompt internal reporting of violations to an appropriate person identified within the Code; and accountability for adherence to the Code". Section 301 assigns responsibility of internal reporting to the audit committee, for "the receipt, retention and treatment of complaints regarding accounting, internal control or auditing matters" and for "confidential, anonymous submission by employees with concerns regarding questionable accounting or auditing matters." SOX also provides anti-retaliation protection for whistleblowers, although this protection has proven to be weak (Dworkin 2007).

As stated in a letter from the Association of Corporate Counsel and undersigned by 250 corporations, failure to require the use of internal compliance programs would have unintended results: “...first, by undermining internal compliance and reporting systems that allow

\footnotetext{
${ }^{5}$ Testimony by Mary L. Shapiro, July 14, 2009. Retrieved from: https://www.sec.gov/news/testimony/2009/ts071409mls.htm
} 
responsible companies to comply with critical regulations and conduct themselves in an ethical manner; and second, by proposing an alternative system which fails to replace existing corporate reporting systems with any effective mechanism to ensure that companies obtain early warnings of burgeoning failures or frauds within their organizations."

The final SEC rules were adopted on May 11, 2011. While the rules do not require internal reporting, they were modified to allow the SEC to provide higher financial rewards to those whistleblowers who first report violations through channels internal to the corporation prior to contacting the SEC. ${ }^{6}$

\section{The Role of Whistleblowers}

One concern about the new regulations was that the SEC would receive a number of frivolous submissions thereby impeding the SEC's ability to process tips received under the program. Bowen, Call and Rajgopal (2010) consider the economic consequences of whistleblowing prior to the introduction of the SEC rule by examining whistleblower allegations reported in the media and a broad sample of whistleblower retaliation cases filed with the US Occupational Safety and Health Administration (OSHA). They find that markets react significantly negatively to whistleblower allegations, and that firms targeted with whistleblowing allegations are more likely to experience earnings restatements and shareholder lawsuits. They also experience weaker future operating and stock market performance. Although the media sample is likely to include only significant cases of misconduct, their findings on the OSHA sample provide evidence that whistleblower allegations do not appear to be frivolous, on average. Call, Martin, Sharp and Wilde (2016) consider whether whistleblower involvement in

\footnotetext{
${ }^{6}$ Evidence to date suggests that many whistleblowers still report through internal compliance systems - the SEC has reported that approximately 80 percent of tips from employees are reported internally first (Henning 2016). However, the concern remains that the program will undercut the effectiveness of existing internal compliance and reporting programs.
} 
enforcement efforts results in more severe enforcement actions. They examine a database of employee whistleblowing allegations and enforcement actions by the SEC and the Department of Justice (DOJ) enforcement actions since SOX. They find that when a whistleblower is involved in the action, regulators are able to impose higher monetary penalties for the firms and thirdparty defendants, such as auditors. They also find that whistleblower involvement is associated with longer prison sentences for culpable employees, and that enforcement proceedings are able to begin more quickly.

\section{The FCA Bounty Program}

Several studies have considered the effectiveness of whistleblower provisions under the FCA. The FCA includes a qui tam provision that allows individuals who are not affliliated with the government to file actions on behalf of the government and receive a portion of any recovered damages (usually 15-25 percent), often referred to as "bounties". Dyck, Morse and Zingales (2010) provide some indirect evidence on the effectiveness of whistleblower provisions under the FCA in detecting fraud. They examine fraud cases in significant U.S. class-action lawsuits to determine who the actor was who first identified the fraud. They find that while employees identified fraud in 18 percent of the sample overall, they represent 41 percent of the cases in the health care sector covered by the whistleblower bounty incentives under the FCA. Lee (2016) considers US state adoptions of the FCA with qui tam provisions, where whistleblowers can claim financial rewards by providing evidence of securities fraud involving state funds (e.g. the New York State Teachers Retirement System holding an investment in a firm that commits fraud). For a sample of firms held by state pension funds that have adopted the FCA, she finds that, following the adoption of the FCA, ex ante estimates of accounting fraud 
decline by 7 percent for these state-held firms. These findings suggest that whistleblowers can play a role in the detection and deterring of misconduct.

\section{The SEC WB Program and Reporting}

The findings by Lee (2016) suggest that whistleblower bounty programs can impact financial reporting outcomes. However, the SEC program covers all publicly traded companies whereas state FCA provisions only impact firms held by state pension funds and only in those states with qui tam provisions. Therefore, the SEC must process a much higher number of complaints. The Agency has received over 18,000 tips since 2011, with the number increasing each year - the agency received 4,218 tips in 2016 alone. To the extent that managers do not believe that the SEC can effectively process this volume of information, they are less likely to change behavior following the introduction of the rules.

Another challenge to the new rules is efforts by managers to defy or circumvent the new SEC rules by muzzling whistleblowers. "Pretaliation" refers to the use of confidentiality and other employment agreements to prevent whistleblowers from providing information to the SEC. In October 2014, eight Democratic members of Congress sent a letter to the SEC Chair expressing concerns that employment agreements were potentially threating the effectiveness of the SEC's program. In 2015 the SEC announced its first enforcement action against a company for pretaliation. (The SEC charged KBR Inc. for requiring employees to sign confidentiality agreements that threatened them with discipline and termination if they disclosed suspected wrongdoing to anyone outside KBR without the company's approval.) If pretaliation is widespread, the new SEC rules are unlikely to be effective in deterring fraud.

While these factors threaten the effectiveness of the SEC WB Program, BMW (2017) provide positive early evidence on its potential effectiveness. They examine investor responses 
to key events leading up to the introduction of the new rules. They compare firms that lobbied against the rules - assumed to be most affected by the rules - to a sample of matched control firms. They find that short-window stock returns are significantly more positive for lobby firms, suggesting that investors expect net benefits to firms following the introduction of the rules. Given these findings and the enhanced resources that Congress has devoted to the SEC program, we predict that the SEC WB Program rules are likely to be effective in reducing aggressive reporting:

H1: Aggressive reporting declines following the introduction of the SEC WB Program.

\section{Firms Most Likely to Be Impacted}

A challenge of this research is attributing changes in aggressive reporting over the sample period to the introduction of the WB Program and not other simultaneous changes. One approach is to exploit cross-sectional differences in changes that can be attributed to the SEC WB Program. This requires having convincing a priori predictions on how the SEC rules differentially affect firms (Leuz and Wysocki 2016). We consider a key firm characteristic in this context - existing internal compliance programs that companies were required to establish under SOX. As noted above, firms were concerned that the new SEC program would undermine existing internal programs and hamper a firm's ability to learn of misconduct and address issues on a timely basis. Since the SEC program provides an alternative channel for reporting misconduct, companies most likely to be affected are those with weaker internal compliance and reporting programs where whistleblowers are more likely to avoid using the internal channel and report directly to the SEC channel instead.

Research on whistleblowing suggests that certain dimensions of an internal compliance and 
reporting program influence the likelihood of whistleblower reporting misconduct internally. Employees are more likely to report internally and less likely to report externally when there is an organizational emphasis on internal compliance systems (Feldman and Lobel 2008). Employees are more likely to report wrongdoing when they think supervisors want to learn about the wrongdoing and that they will take action, if warranted (Miceli et al. 2008). Research also indicates that a whistleblower program is more effective when an employee has reporting options including the option to report directly to the board of directors rather than to managers. Having reporting options helps circumvent the problem of "blocking and filtering" by middle managers and executives (Moberly 2006). ${ }^{7}$ Fear of retaliation is also an important dimension. Whistleblowers are less likely to report internally when they perceive a threat of retaliation by the organization, immediate supervisors, or co-workers (Near and Miceli 1996).

We predict that firms most likely to be affected by the SEC whistleblower regulations are firms that had weak internal compliance and reporting programs when the regulations were introduced. BMW (2017) find that investor responses to announcements relating to the introduction of the SEC WB Program were more significantly more positive for firms with weak internal compliance programs. This suggests that investors expect greater benefits of regulation for these firms. If firms with weaker internal compliance and reporting programs face greater threat of external rather than internal reporting by employees, they are more likely to alter their behavior in response to the new rules:

H2: The reduction in aggressive reporting following the introduction of the SEC WB Program is greater for firms with weak internal compliance and reporting programs.

\footnotetext{
${ }^{7}$ A number of supporters of the SEC proposal argued against the SOX system of reporting internally noting that employees should not be required to report concerns to their "corrupt bosses".
} 


\section{Mechanism for Change following the SEC WB Program}

Given greater threat of external reporting by employees, firms have incentives to make structural changes to reduce the probability of fraud from occurring. One potential avenue is to improve internal control systems. Internal controls are those procedures within a company that are designed to reasonably ensure compliance with the company's policies, including financial reporting policies. Since the Foreign Corrupt Practices Act of 1977, all publicly traded US companies have been required to devise and maintain internal controls sufficient to provide reasonable assurance that financial statements are prepared in conformity with GAAP. In response to a number of high-profile financial reporting fraud cases, SOX later enhanced this responsibility with the stated goal: "To protect investors by improving the accuracy and reliability of corporate disclosures made pursuant to securities laws, and for other purposes." Section 302 of SOX requires that the CEO and CFO of a company certify that the disclosure processes and controls that are in place are capable of consistently producing financial information stakeholders can rely on. Auditors must report on the reliability of management's assessment of these controls under Section 404. Internal controls are one mechanism for ensuring high quality financial reporting.

While there is some debate in the literature over whether better internal controls can reduce intentional misrepresentation resulting from management override of internal controls or collusion (Kinney 2005), recent research does support an association between ICWs and reporting quality. Ashbaugh-Skaife, Collins, Kinney and LaFond (2008) argue that weak internal controls increase both unintentional and intentional errors. If controls are weak, information will be more noisy and less reliable making it more difficult for managers to determine reliable accrual amounts. Further, managers of firms with weak internal controls can more readily 
override the controls and intentionally prepare biased accrual estimates. They find that firms that report ICWs have significantly larger positive and larger negative abnormal accruals and that firms that remediate their weaknesses report an increase in accrual quality. Doyle et al (2007a) also report significantly lower accrual quality for firms reporting ICWs. Chan, Farrell and Lee (2008) document a positive association between ICWs and restatements, and Donelson, Ege and McInnis (2016) find that firms that disclose material ICWs are significantly more likely to have a future fraud revelation, particularly for entity-level controls. This research supports an association between internal control quality strength and financial reporting quality.

If firms improve internal controls following the introduction of the SEC WB Program, the frequency of ICWs should decrease:

H3: The incidence of internal control weaknesses declines following the introduction of the SEC WB Program.

More directly, we also consider whether firms improve their internal compliance and reporting programs. If employees at firms with weak compliance programs have incentives to report externally, those firms can respond by strengthening those programs in the hopes of encouraging potential whistleblowers to report internally first:

H4: The incidence of internal control weaknesses relating to internal compliance programs declines following the introduction of the SEC WB Program. 


\section{RESEARCH DESIGN AND RESULTS}

\section{Event Periods}

The WB Program was approved by the SEC on May 25, 2011 and became effective on August 12, 2011. However, the SEC first introduced the idea for the program in 2009 and released the detailed proposal of the rules in December 2010. Further, a whistleblower was eligible for an award for original information provided on or after July 22, 2010 so long as they complied with all of the rules when they did become effective. Given these provisions, we define the PRE WB Program period as 2006 to 2009 and the POST period as $2010-2014 .^{8}$

\section{Sample and Variable Measurement - Abnormal Accruals Analysis}

Our sample selection process is outlined in Table 1 column 1. We obtain our sample from the Annual North American Compustat database for the years 2006 to 2015. (We require 2015 data to estimate accruals.) Since the SEC WB Program covers violations of the federal securities laws, we focus our analysis on US public companies. ${ }^{9}$ We select firms where the Foreign Incorporate Codes (FIC) equals "USA" and where the Stock Exchange Code (EXCHG) equals $11,12,13,14,15,16,17$ or 18 . To reduce the likelihood that our findings are driven by other changes introduced by the Dodd Frank Act and because traditional accruals measures are not meaningful for financial sector firms, we eliminate all firms with SIC codes in the 6000-6999 range. For the accruals analysis, we require that firms have non-missing data for the required regression variables, total assets greater than zero, and that each firm/year belong to a SIC twodigit group with at least 20 observations. This yields a sample of 10,138 firm-year observations.

8 We later consider the robustness of our findings to the definition of PRE and POST.

${ }^{9}$ Note that the program can also affect private companies that violate securities laws, such as in providing falsified information when seeking investors. 


\section{Measuring the Impact of the SEC WB Program on Aggressive Financial Reporting}

Our measure of aggressive financial reporting is based on the McNichols (2002) accruals measure adapted from Dechow and Dichev (2002) where accruals are mapped into past, current and future operating cash flows, changes in revenue and property, plant and equipment. Jones, Krishnan and Melendrez (2008) compare 10 measures of earnings management to assess whether these models detect actual cases of fraud and find that the Dechow and Dichev (2002) and McNichols (2002) accruals measures consistently exhibit the highest associations with fraud cases. We measure abnormal accruals as:

$$
\begin{aligned}
& \mathrm{ACC}_{\mathrm{it} /} / \mathrm{A}_{\mathrm{it}-1}=\left(\hat{\lambda}_{0}+\hat{\lambda}_{1} \mathrm{CFO}_{\mathrm{it}-1} / \mathrm{A}_{\mathrm{it}-2}+\hat{\lambda}_{2} \mathrm{CFO}_{\mathrm{it}} / \mathrm{A}_{\mathrm{it}-1}+\hat{\lambda}_{3} \mathrm{CFO}_{\mathrm{it}+1} / \mathrm{A}_{\mathrm{it}}+\hat{\lambda}_{4} \Delta \mathrm{REV}_{\mathrm{it}} / \mathrm{A}_{\mathrm{it}-1}+\right. \\
& \left.\left.\hat{\lambda}_{5} \mathrm{PPE}_{\mathrm{it}} / \mathrm{A}_{\mathrm{it}-1}\right)\right]+\varepsilon_{\mathrm{it}}
\end{aligned}
$$

where $\mathrm{ACC}_{\mathrm{it}}$ is income before extraordinary items minus cash flow from operations at the year $t, A_{i t}$ is total assets at year $t, C O_{i t}$ is cash flow from operations in the year $t, \Delta \mathrm{REV}_{\text {it }}$ is change in revenue in the year $\mathrm{t}$, and $\mathrm{PPE}_{\mathrm{it}}$ is gross property plant and equipment at the beginning of the year t. We estimate the model cross-sectionally by two-digit SIC group and by year (Ali and Zhang 2015) requiring a minimum of 20 observations per group/year. All necessary data is obtained from Compustat (North America). Residuals from the estimated model represent abnormal, or discretionary, accruals. We use the absolute value of this residual, $A B S_{-} D A$, as our measure of aggressive reporting. Greater values represent more aggressive reporting, and can be either income-increasing (such as premature recognition of revenue) or decreasing (such as overstatement of expenses to create "cookie jar" reserves).

To assess the impact of the SEC WB program on aggressive reporting we estimate the following Tobit regression (we use a Tobit model given that observations are truncated at zero): 


$$
\begin{aligned}
& A B S \_D A=\alpha_{0}+\alpha_{1} P O S T+\alpha_{2} R E S T R U C T U R E+\alpha_{3} \text { GROWTH }+\alpha_{4} \% L O S S+\alpha_{5} I N V E N T O R Y+ \\
& \alpha_{6} I N T \text { INTENSITY }+\alpha_{7} N O_{-} I N T E N S I T Y+\alpha_{8} C A P \_I N T E N S I T Y+\alpha_{9} S I Z E+\alpha_{10} B M+ \\
& \alpha_{11} \text { ZSCORE }+\alpha_{12} \text { WRITE-OFF }+\alpha_{13} \text { AUDITOR }+\alpha_{14} S T D \_C F O+\alpha_{15} S T D \_S A L E+\alpha_{16} \\
& M \& A+\sum I N D U S T R Y+\varepsilon
\end{aligned}
$$

We define POST as an indicator equal to one for firm observations in years 2010 to 2014, and zero otherwise. We include a number of additional measures to control for innate firm characteristics that affect the measurement of accruals. Firms with restructurings (RESTRUCTURE), mergers and acquisitions $(M \& A)$, or poor financial performance (ZSCORE) record larger asset impairments and write-offs (WRITE-OFF), affecting accruals. Firms exhibiting rapid growth $(G R O W T H)$ and low book-to-market ratios $(B M)$ tend to build up inventory (INVENTORY) in anticipation of future increased sales (Ashbaugh-Skaife et al. 2008). Accruals quality is positively related to firm size (SIZE) and negatively related to the portion of losses reported by the firm (\%LOSS) (Dechow and Dichev 2002). To capture the effect of asset structure on accruals, we include measures for investment in intangible assets (INT_INTENSITY), lack of intangible assets (NO_INTENSITY) and property, plant and equipment (CAP_INTENSITY) (Francis et al. 2005). Given that firms with more volatile operations have more variable accruals, we include measures for the standard deviation of operating cash flows (STD_CFO) and sales (STD_SALE) (Dechow and Dichev 2002). We also control for auditor quality (AUDITOR) by including an indicator variable for the six largest audit firms (Francis et al. 1999). We describe the measurement of these variables in the Appendix, Panel A.

Table 2 panel A presents descriptive statistics for the variables in equation (1). To control for outliers, we winsorize all continuous variables at the $1^{\text {st }}$ and $99^{\text {th }}$ percentiles. The mean (median) for our measure of interest $A B S \_D A$ is $0.051(0.032)$, similar to previous studies. We report 
considerable variation for many of the independent variables such as size and intangible and capital intensity highlighting the importance in controlling for these variables in our regressions. A number of firms report involvement in restructuring and merger and acquisitions activities. On the other hand, a high proportion of firms ( 84.7 percent) are audited by one of the largest six audit firms.

Results - The Impact of the SEC WB Program on Aggressive Reporting-Multivariate Analysis

We report the results for the estimation of regression equation (1) in Table 3. We note that many of the control variables are significant in explaining abnormal accruals. In column 1, the dependent variable is the absolute value of abnormal accruals $\left(A B S \_D A\right)$ estimated using the cross-sectional McNichols (2002) model. Here we find that the coefficient for POST is negative and significant at the 0.01 level, consistent with aggressive reporting decreasing following the introduction of the SEC WB Program. Relative to the intercept of 0.070 , the negative coefficient of -0.008 suggests that absolute abnormal accruals decreased by $11 \%$. We also consider whether this reduction applies to both income-increasing and income-decreasing earnings management. In column 2, the dependent variable is the value of positive abnormal accruals (POS_DA) using the cross-sectional McNichols (2002) model; in column 3, the dependent variable is the value of negative abnormal accruals (NEG_DA). We find significant changes for both in the direction predicted - reduced positive abnormal accruals (coefficient of -0.006 , significant at the 0.01 level), and reduced negative abnormal accruals (coefficient of 0.0 .13 significant at the 0.01 level). This evidence provides support for Hypothesis 1 that aggressive reporting decreased following the introduction of the new SEC whistleblower rules. 


\section{Additional Tests}

As discussed earlier, we define POST as an indicator equal to one for firm observations in years 2010 to 2014 since the detailed proposal of the rules was released in December 2010 and whistleblowers were eligible for an award for original information starting in July 2010. In sensitivity tests, we define TRANSITION as an indicator equal to one for firm observations in 2010 and POST2 as an indicator equal to one for firm observations in years 2011 to 2014 since the rules were officially enacted in 2011. Results (untabulated) indicate that the coefficient for TRANSITION is significantly negative (at the 0.01 ) for the absolute value of abnormal accruals and for positive accruals in columns 1 and 2 and significantly positive for negative accruals (at the 0.01 level) for column 3. Similarly, the coefficient for POST2 is also significantly negative (at the 0.01 level) for columns 1 and 2 and significantly positive (at the 0.01 level) for column 3 . This finding is consistent with firms being aware of the regulatory proposals and already taking action in response to the proposed rules in 2010.

In columns 4 through 6 we include an indicator variable $Q U I T A M$ to consider the impact of the whistleblower regulations on a subset of firms already covered under the qui tam provision of the FCA. Following Dyck et al. (2010), we define $Q U I T A M$ as an indicator variable equal to one for firms in the health care sector where the government is a significant buyer: firms in drugs, drug proprietaries, and druggists' sundries (SIC code 5122); health care providers (SIC codes 8000-8099); health care related firms in Business Services (health care firms in SIC codes 7380 and 7389); and, firms that appear on the "100 companies receiving the largest dollar volume of prime contract awards" list in any of the three years before 2010, and zero otherwise. Since firms with government contracts were already covered by the whistleblower provisions of the FCA from the beginning of our entire sample period, they are less likely to be impacted by the new 
SEC rules. At the bottom of the table, we report the significance of the sum of the coefficients $P O S T$ and $P O S T+P O S T^{*}$ QUIT TAM to test whether abnormal accruals decline significantly for these firms. As reported in column 4, the sum of the coefficients is not significantly different from zero. We report similar results in columns 5 and 6 . These results suggest that the SEC whistleblower provisions did not significantly impact firms already covered by whistleblower provisions under the FCA.

In untabulated results we also consider an alternative measure for aggressive reporting. Using a sample of firms charged by the SEC for having committed fraud, Beneish (1999) develops a model that estimates the probability of a firm manipulating its earnings using financial statements variables from the forensic accounting literature. Following Beneish, Lee and Nelson (2013) we use the coefficients estimated from the Beneish model and classify firms as earnings manipulators when their score exceeds 1.78 . We then test for changes in the probability of manipulation by estimating a regression model that controls for other determinants of fraud. Similar to our findings in Table 3, we find that the probability of manipulation declines significantly in the POST period $(\mathrm{p}<0.05)$ for our sample firms.

To provide further evidence that the results in Table 3 columns 1 through 3 are not driven by other changes over the sample period, we compare U.S. firms to a sample of Canadian firms over the same period. Canada did not have a whistleblower program in place during our sample period $2006-2014 .{ }^{10}$ As described in Table 1 column 2, our sample of Canadian firms excludes firms in the financial industry and cross-listed firms. Our resulting sample is 1,488 firm-years over the

\footnotetext{
10 The Ontario Securities Commission (OSC) was considering introducing a whistleblower program similar to the U.S. during our sample period. The Commission began discussing possible tools to enhance enforcement in 2011 and published a consultation paper in February of 2015. New rules similar to the SEC were introduced in October 2015. Many of the Canadian firms in our sample are listed on the Toronto Stock Exchange and are therefore subject to regulation by the OSC. To the extent that Canadian firms anticipated the introduction of these new regulations, then our tests our biased against us finding evidence of reduced aggressive reporting for U.S. firms in difference-in-differences tests.
} 
sample period. As reported in Table 2 panel B, the mean (median) for our measure of aggressive reporting $A B S \_D A$ is $0.078(0.049)$.

Results for our difference-in-differences tests are reported in Table 4. Here, we include an indicator variable TREATMENT that equals one for U.S. firms and zero otherwise, and an interaction term POST*TREATMENT for changes in aggressive reporting for U.S. firms relative to Canadian firms. As reported in column 1, we find that the coefficient for the variable TREATMENT is significantly negative, suggesting that Canadian firms report more aggressively, on average, than U.S. firms. The coefficient of interest for the variable POST*TREATMENT is also negative and significant at the 0.05 level. In columns 2 and 3 we reported results separately for positive and negative abnormal accruals. The interaction term is not significant for the regression model including only $P O S_{-} D A$ (column 2) but is significant for the regression including only $N E G \_D A$ (column 3). These results suggest that U.S. firms reduced their level of aggressive reporting more significantly than Canadian firms following the introduction of the SEC whistleblower program in the U.S., particularly for negative abnormal accruals.

Testing for Cross-sectional Variation in the Impact of the SEC WB Program on Aggressive Reporting

Hypothesis 2 predicts that the reduction in aggressive financial reporting is more pronounced for firms with weaker internal compliance and reporting programs prior to the new WB Program. Ideally we would like to measure the strength of a firm's internal compliance program, as employees are more likely to report internally if their internal programs are strong. Companies describe their internal compliances program within their Code of Ethics. While a company's current Code of Ethics is typically available on its website, companies are not 
required to (and generally do not) archive previous Codes. This is problematic because we require evaluations of internal compliance and reporting programs when the SEC rules were first introduced as companies may have responded to the WB Program by improving their internal programs to encourage employees to report misconduct internally first. Given that Codes are not archived, we rely on data from BMW (2017) who construct a firm-level index of internal compliance and reporting program strength for a sample of firms who lobbied against the SEC WB Program and a matched control sample. BMW (2017) develop their coding along these three dimensions of interest and use the recommendations provided in the International Chamber of Commerce guideline on whistleblowing (ICC 2008) to guide them. They also use several independent sources to ensure construct validity. ${ }^{11}$

We are interested in the three aspects of program strength reported in BMW (2017) as they relate to the probability of an employee reporting internally: the importance that the firm places on the program within the Code ( $W B \_P E$ - program efficacy); the availability of reporting options including those independent from management ( $W B \_I R-$ independence of reporting); and, the protection of the whistle blower (WB_PROT - whistleblower protection). Based on the BMW (2017) coding, the maximum scores for each category are: 3 for $W B \_P E, 8$ for $W B \_I R$ and 7 for $W B \_P R O T . W B \_T O T$ is the sum of the three components with a total maximum score of 18. We reverse code these scores (maximum score - actual score) so that higher scores represent weaker internal compliance programs. The total sample from BMW (2017) with necessary data for our tests is 224 firms and 1,502 firm-years.

\footnotetext{
${ }^{11}$ For a detailed description of the index and the validity tests conducted on the measure, see BMW (2017) section 5 and Appendix 1.
} 
To test hypothesis 2 , we include the variable $W B_{-} T O T$ and the interaction variable $P O S T^{*} W B_{-} T O T$ in equation (1). We expect reductions for aggressive reporting to be greater for firms with weaker internal programs, and therefore predict a negative sign for this variable. We report results from our tests in Table 4. In column (1) we include the BMW (2017) variable WB_TOT and the interaction variable $P O S T^{*} W B_{-} T O T$ in equation (1). The coefficient for the interaction variable is negative and statistically significant at the 0.05 level. Given that higher levels of $W B_{-} T O T$ denote weaker internal compliance programs, these findings suggest that reductions for aggressive reporting are greater for firms with weaker programs. In columns (2), (3) and (4) we replace $W B_{-} T O T$ and with the subcomponent scores: $W B_{-} P E$ for program efficacy, $W B_{-} I R$ for independence of reporting, and $W B_{-} P R O T$ for protection of the whistleblower. The interaction term for $W B_{-} P E$ is not statistically different from zero but both WB_IR and WB_PROT are negative and statistically significant at the 0.05 level. This suggests that aggressive reporting decreased more for firms where employees had fewer reporting options independent from management, and for firms that did not promise strong protection to potential whistleblowers. These firms may have perceived the likelihood of employees reporting directly to the SEC to be higher than for other firms, providing a strong motivation to reduce the likelihood of misconduct. Overall, these findings support Hypothesis 2.

In column (5) we also consider whether reductions differ across firms that lobbied against the new rules compared to a control group of firms that did not lobby. Here the interaction term is not significant at conventional levels. Therefore, while BMW (2017) find that lobby firms had weaker internal compliance programs than non-lobby firms on average, variation in compliance program strength between individual firms within each group are still significant, and 
compliance program strength appears to be a better predictor of changes in reporting than the act of lobbying itself.

\section{Sample and Variable Measurement - Internal Controls Analysis}

In this section, we consider the impact of the SEC whistleblower program on firms' internal control systems. Our sample selection for this analysis is reported in columns 3 and 4 of Table 1. For this analysis we exclude firms with missing SOX Section 404 (Section 302) audit data from Audit Analytics and/or missing data for the regression variables. Because SOX 404 was not effective for non-accelerated filers until 2007 / 2008, we also exclude firms with a market capitalization of less than $\$ 75$ million in 2006. The final sample size for the Section 404 (302) analysis is $19,611(21,260)$.

Direct measures of internal control quality are not publicly available. Most researchers rely on the reporting of ICWs to proxy for (poor) internal control quality. Section 302 ICWs are those reported by management that relate to deficiencies in the disclosure processes and controls needed for reliable financial reporting. For Section 404, auditors attest to managements' assertions regarding these controls. If auditors are conservative in their identification of material weaknesses, Section 404 weaknesses may include a higher proportion of less severe ICWs than Section 302. Doyle et al. (2007a) consider ICW reporting under both Section 302 and Section 404 regimes and find significantly lower accrual quality for firms reporting ICWs under Section 302 but not Section 404. They conclude that Section 404 ICWs are less informative than Section 302 in identifying firms with real financial reporting concerns. On the other hand Rice and Weber (2012) find that firms are strategic in their Section 404 disclosures, and that detection and disclosure incentives play a role in whether a material weakness is disclosed. Given limitations of each measure, we consider both reporting regimes in our analysis. 
To assess the impact of the SEC WB Program on internal control quality, we estimate the following Probit regression for the probability of the company experiencing an internal control weakness reported under Section 302:

$$
\begin{aligned}
\operatorname{Pr}(I C W)= & \beta_{0}+\beta_{1} \text { POST }+\beta_{2} \text { MARKETCAP }+\beta_{3} \text { FIRM AGE }+\beta_{4} \text { AGGREGATE LOSS } \\
& +\beta_{5} \text { SEGMENTS }+\mathrm{B}_{6} \text { FOREIGN TRANSACTIONS }+\beta_{7} \text { ACQUISITION VALUE } \\
& +\beta_{8} \text { EXTREME SALES GROWTH }+\beta_{9} \text { RESTRUCTURE }+\varepsilon
\end{aligned}
$$

The dependent variable, $I C W$, is an indicator variable equal to one if a firm has a SOX Section 404 (302) internal control weakness reported in Audit Analytics during the fiscal year and zero otherwise. Again, we define POST as an indicator equal to one for firm observations in years 2010 to 2014, and zero otherwise. We follow Doyle et al. (2007b) and include a number of control variables for determinants of weaknesses in internal control. These include: firm size measured as market capitalization (MARKETCAP), as larger firms have greater resources and enjoy greater economies of scale when developing internal control; the age of the firm (FIRM $A G E$ ), as older firms have more developed systems; incidence of losses in the current and prior year (AGGREGATE LOSS) as firms with stronger financial health have stronger internal control systems; number of geographic and operating segments (SEGMENTS) and foreign transactions (FOREIGN TRANSACTIONS) to control for the complexity of operations; acquisitions (ACQUISITION VALUE) and rapid growth (EXTREME SALES GROWTH) as these firms may outgrow existing internal controls and need time to establish new procedures: and firms undergoing restructuring (RESTRUCTURING CHARGE) to control for the effect of downsizing and increased complexity of accruals and write-downs during restructuring on internal control. We describe the measurement of these variables in the Appendix, Panel B. 
If firms perceive a threat of employees reporting misconduct directly to the SEC, they have incentives to make structural changes to reduce the probability of misconduct. Hypothesis 3 predicts that one way to improve financial reporting and reduce the probability of misconduct is through the improvement of internal control systems. Table 6 reports descriptive statistics for the variables in regression equation (2) for the Section 404 sample in Panels A and for the 302 sample in Panel B. The mean value for the Section 404 (302) sample of ICWs is $0.061(0.091)$. The average firm in our Section 404 (302) sample is 19.8 (20.2) years suggesting that internal controls are likely well established for many of the sample firms. However, firms report organizational complexity through reporting segments (means of 3.2 and 3.3 in Panels A and B) and foreign transactions (means of 0.32 in both Panels A and B). Also, a number of firms report losses, acquisitions and restructuring and extreme sales growth all of which pose challenges to establishing and maintaining effective internal controls.

Results for the estimation of regression equation (2) are reported in Table 7. In column 1, we report results using the dependent variable, ICW, from the Section 404 reporting regime; column 2 reports results under Section 302. Coefficients for the control variables are generally significant and consistent with Doyle et al. (2007b). The results for our coefficient of interest, POST, are consistent with our predictions in Hypothesis 3. For both regimes, the coefficient is negative and significant at 0.01 level providing evidence that the frequency of internal control weaknesses decreased significantly following the introduction of the SEC WB Program.

\section{Internal Compliance and Reporting Programs}

As previously noted, it is not possible to evaluate the quality of a firm's internal compliance and reporting programs when the SEC rules were first introduced, therefore it is not possible to 
measure the change in quality directly for the overall sample. Instead, we rely on disclosures of ineffective controls under Section 302 of SOX reported by Audit Analytics. The category most relevant to our analysis is Code 82 - "inadequate or not-implemented internal whistleblower policy" (including an ethics or anonymous hotline). We also consider two additional categories that may also be related to the effectiveness of the internal compliance programs. Because the design of internal programs is described in the firm's Code of Ethics, we consider Code 84 - “a problem involving the formulation or implementation of an effective Code of Ethics". Effectiveness of the Code of Ethics is dependent on the support by management in communicating, supporting and enforcing the code and employees are more likely to report wrongdoing when they believe management wants to learn of misconduct and is committed to taking action against misconduct. Therefore we also consider Code 67 - a problem involving senior management tone or "tone at the top". For this analysis, we estimate equation (2) where the dependent variable, $I C W$, is an indicator variable equal to one if a firm has a SOX Section 302 Code 82 (and/or 84 and/or 67) weakness reported in Audit Analytics during the fiscal year and zero otherwise.

Hypothesis 4 predicts that firms have incentives to improve their internal compliance programs after the introduction of the rules to reduce the likelihood of employees reporting externally to the SEC rather than using internal channels. We collect data on the reporting of ineffective controls from Audit Analytics for the Code 82, Code 84 and Code 67. Descriptive statistics are reported in Table 8 . We see that the number and frequency of ineffective control disclosures is very low. For example, only 32 firms $(0.51 \%)$ report a Code 82 weakness, 62 $(0.98 \%)$ a Code 84 and $52(0.82 \%)$ a Code 67 weakness in 2010. Still, when we compare frequencies before and after the introduction of the SEC rules, we observe a reduction in the 
frequency of reporting. For Code 82 - "Whistleblower policy/ethics hotline missing/inadequate" - the frequency decreases from $0.64 \%$ in the PRE period (2006-2009) to $0.34 \%$ in the POST period (2010 - 2014). Similarly, for Code 84 - "a problem involving the formulation or implementation of an effective Code of Ethics" - the frequency decreases from $1.04 \%$ to $0.65 \%$, and Code 67 - problems involving senior management tone or "tone at the top" - the frequency decreases from $1.55 \%$ to $0.41 \%$.

In Table 9 we report the results from the estimation of regression equation (2). One challenge for this analysis is the rarity of ICWs in these categories. King and Zeng (2001) note that where the binary dependent variable has "dozens to thousands" more zeros than ones, standard procedures like logistic regression can seriously underestimate the probability of rare events. To address this issue, we employ the Penalized Maximum Likelihood Estimation (Firth, 1993) to reduce potential bias in estimating the effect of the SEC WP program on internal control weaknesses ${ }^{12}$. The dependent variable in column 1 is a weakness in the firm's internal WB Policy (Code 82) and is equal to one if the code appears in any of four quarters in the fiscal year, or zero otherwise. The dependent variable in column 2 is a weakness in the firm's internal WB Policy (Code 82) and/or Code of Ethics (Code 84); the dependent variable in column 3 is a weakness in the firm's internal WB Policy (Code 82) and/or Code of Ethics (Code 84) and/or Tone at the Top (Code 67).

A number of the coefficients for the control variables are significant and consistent in sign with Doyle et al. (2007b). The likelihood of a weakness in a firm's internal WB policy is increasing in the incidence of losses, organizational complexity (number of segments and foreign transactions), and restructuring activities. However, MARKETCAP and FIRM AGE are not

\footnotetext{
12 Leitgöb (2013) compares three ways to deal with rare events: the Exact Logistic Regression, the Bias Correction Method proposed by King and Zeng (2001), and Penalized Maximum Likelihood Estimation proposed by Firth (1993). He finds that the Firth method performs best in simulations and estimates are unbiased.
} 
significant in column 1 suggesting that the likelihood of a weakness is a firm's internal WB policy is not associated with firm size or age. Also, EXTREME GROWTH and ACQUISITION VALUE are not significant in any of the three analyses.

The coefficient for the variable of interest, POST, is negative and significant at the 0.05 level or higher in all three columns, consistent with our predictions in Hypothesis 4. These results are consistent with firms making improvements to internal WB policies, including ethics hotlines, after the introduction of the SEC rules. The potential motivation for these improvements may have been made to reduce the likelihood of employees reporting externally to the SEC rather than using internal channels.

\section{CONCLUSION}

In this paper, we consider the effect of the SEC WB Program in deterring aggressive financial reporting by US firms. We measure aggressive reporting using the absolute value of abnormal accruals and document a significant reduction in accruals of approximately 11 percent after controlling for other factors known to affect accruals measurement. This reduction is observed for both positive and negative accruals. A challenge of our research is attributing changes in aggressive reporting over the sample period to the introduction of the WB Program and not other simultaneous changes. First, we find that the SEC program did not impact firms already covered under whistleblower provisions of the FCA. In additional tests we compare changes in reporting for U.S. firms to Canadian firms over the sample time period. In a difference-in-differences design, we find that reductions in aggressive reporting are significantly greater for U.S. firms than for Canadian firms over the same time period. Further, we also follow the suggestion of Leuz and Wysocki (2016) and exploit cross-sectional differences in changes 
that can be attributed to the SEC WB Program. By using a smaller sample of firms with ratings of internal reporting program quality just prior to the introduction of the SEC WB Program from BMW (2017), we are able to demonstrate that reductions in aggressive reporting are greater for firms with weaker internal reporting programs. Employees of these firms are more likely to choose to report to the SEC directly as internal channels provide fewer reporting options independent of management and/or provide less protection against retaliation. These findings increase our confidence that the changes we observe are attributable to the new regulation.

We also consider the effect of the SEC WB Program on internal controls. We find that reporting of internal control weaknesses decreased significantly in the years following the introduction of the SEC WB Program. In additional analysis, we also find a significant decrease in the reporting of weaknesses relating specifically to a firm's internal WB Policy (including ethics hotlines), consistent with firms improving internal compliance and reporting systems to encourage internal reporting.

Collectively, our findings provide evidence that the SEC whistleblower program is effective in achieving the goal of deterring securities violations as it relates to fraudulent reporting. Further research can consider the effect of the program on other securities violations, including inside trading, offering fraud, and violations of the Foreign Corrupt Practices Act. 


\section{REFERENCES}

Ali, A. and W. Zhang. 2015. CEO tenure and earnings management. Journal of Accounting and Economics 59 (2015): 60-79.

Ashbaugh-Skaife, H., D.W. Collins, W.R. Kinney, Jr., and R. LaFond. 2008. The effect of SOX internal control deficiencies and their remediation on accrual quality. The Accounting Review 83: 217-250.

Baloria, V., C. Marquardt, and C. Wiedman. 2017. A lobbying approach to evaluating the whistleblower provisions of the Dodd-Frank Reform Act of 2010. Contemporary Accounting Research 34 (3): 1305-1339.

Beneish, D. M. 1999. The detection of earnings manipulation. Financial Analysts Journal (September/October): 24-36.

Beneish, D. M., C. M. C. Lee and C. D. Nichols. 2013. Earnings manipulation and expected returns. Financial Analysts Journal 69 (2): 57-82.

Bowen, R., A. Call, and S. Rajgopal. 2010. Whistle-blowing: Target firm characteristics and economic consequences. The Accounting Review 85 (4): 1239-1272.

Call, A. C., G. S. Martin, N. Y. Sharp and J. H. Wilde. 2016. Whistleblowers and outcomes of financial misrepresentation enforcement actions. Working Paper, December 2016.

Chan, K., B. Farrell, and P. Lee. 2008. Earnings management of firms reporting material internal control weaknesses under Section 404 of the Sarbanes-Oxley Act. Auditing: A Journal of Practice and Theory 27: 161-179.

Coates, J. C. and S. Srinivasan. 2014. SOX after ten years: A multidisciplinary review. Accounting Horizons 28(3): 627-671.

Cohen, D. A. Dey and T. Lys. 2008. Real and accrual-based earnings management in the preand post-Sarbanes-Oxley periods. The Accounting Review 83: 757-787.

Dechow, P., and I. Dichev. 2002. The quality of accruals and earnings: The role of accrual estimation errors. The Accounting Review 77: 35-59.

Donelson, D.C., M. Ege and J. McInnis. 2016. Internal control weaknesses and financial reporting fraud. Auditing: A Journal of Practice and Theory.

Doyle, J.T., W. Ge and S. McVay. 2007a. Accruals quality and internal control over financial reporting. The Accounting Review 82: 1141-1170.

Doyle, J.T., W. Ge and S. McVay. 2007b. Determinants of weaknesses in internal control over financial reporting. Journal of Accounting and Economics 44: 193-223. 
Dworkin, T. M. 2007. SOX and whistleblowing. Michigan Law Review 105 (2007): 1757-80.

Dyck, A., A. Morse, and L. Zingales. 2010. Who blows the whistle on corporate fraud? The Journal of Finance 65 (6): 2213-2253.

Feldman, Y. and O. Lobel. 2008. Decentralized enforcement in organizations: An experimental approach, Regulation \& Governance 2 (2): 165-192.

Firth D. 1993. Bias reduction of maximum likelihood estimates. Biometrika 80: 27-38.

Francis, J., E. Maydew and C. Sparks. 1999. The role of Big 6 auditors in the credible reporting of accruals. Auditing: A Journal of Practice \& Theory 18: 17-34.

Francis, J., R. LaFond, P. Olsson and K. Schipper. 2005. The market pricing of accruals quality. Journal of Accounting and Economics 39: 295-328.

Henning, P.J. 2016. Whistle-blowing insiders: 'Game changer for the S.E.C.'. Wall Street Journal, September 6, 2016.

Iliev, P. 2010. The effect of SOX section 404: Costs, earnings quality, and stock prices. Journal of Finance 45: 1163-1196.

International Chamber of Commerce (ICC). 2008. ICC guidelines on whistleblowing. Available at: http://www.iccwbo.org/uploadedFiles/ICC\%20Guidelines\%20 Whistleblowing\%20\%20as\%20adopted\%204_08\%282\%29.pdf.

Jones, K., G. Krishnan, and K. Melendrez. 2008. Do models of discretionary accruals detect actual cases of fraudulent and restated earnings? An empirical analysis. Contemporary Accounting Research 25 (2): 499-531.

King, G. and Zeng, L. 2001. Logistic Regression in Rare Events Data. Political Analysis 9: 137163.

Lee, H. 2016. Does the threat of whistleblowing reduce accounting fraud? Working Paper, October 27, 2016.

Leitgöb, Heinz. 2013. The problem of rare events in Maximum Likelihood Logistic Regression Assessing potential remedies. Working Paper, 2013 European Survey Research Association Meetings.

Leuz, C. and P. D. Wysocki. 2016. The economics of disclosure and financial reporting regulation: Evidence and suggestions for future research. Journal of Accounting Research 54 (2): 525-622. 
McNichols, M. F. 2002. Discussion of "The quality of accruals and earnings: The role of accrual estimation errors." The Accounting Review 77: 61-69.

Miceli, M.P., J.P. Near and T.M. Dworkin. 2008. Whistle-blowing in Organizations. New York: Pschology Press, Taylor \& Francis Group.

Moberly, R. 2006. Sarbanes-Oxley's structural model to encourage corporate whistleblowers. BYU Law Review 2006: 1107-80.

Near, J.P. and M.P. Miceli. 1996. Whistle-blowing: Myth and reality. Journal of Management 22: 507-526.

Rice, S.C. and D.P. Weber. How effective is internal control reporting under SOX 404? Determinants of (non-) disclosure of existing material weaknesses. Journal of Accounting Research 50 (3): 811-843.

Securities and Exchange Commission (SEC). 2016a. Sean McKessy, Chief of Whistleblower Office, to Leave SEC. Press Release 2016-136, July 8, 2016. Available at https://www.sec.gov/news/pressrelease/2016-136.html.

SEC. 2016b. SEC Whistleblower Program Surpasses \$100 Million in Awards. Press Release 2016-173, August 20, 2016. Available at https://www.sec.gov/news/pressrelease/2016173.html. 


\section{Appendix Variable Definitions}

\begin{tabular}{|c|c|}
\hline Variables & Definitions \\
\hline Panel A: & Accruals Analysis \\
\hline$A B S \_D A$ & $\begin{array}{l}\text { The absolute value of abnormal accruals estimated by using the cross- } \\
\text { sectional McNichols (2002) model. }\end{array}$ \\
\hline POST & $\begin{array}{l}\text { An indicator variable that equals one if a firm-year's fiscal end falls } \\
\text { between Jan 1, } 2010 \text { and Dec } 31,2014 \text {, and zero otherwise. }\end{array}$ \\
\hline QUI TAM & $\begin{array}{l}\text { An indicator variable that equals one if a firm belongs to the one of the } \\
\text { following: drugs, drug proprietaries, and druggists' sundries (SIC code } \\
5122 \text { ); health care providers (SIC codes } 8000-8099 \text { ); health care related } \\
\text { firms in Business Services (health care firms in SIC codes } 7380 \text { and } \\
7389 \text { ); and, firms that appear on the "100 companies receiving the } \\
\text { largest dollar volume of prime contract awards" list in any of the three } \\
\text { years before 2010; and zero otherwise. }\end{array}$ \\
\hline TREATMENT & $\begin{array}{l}\text { An indicator variable that equals one if the firm is a U.S. firm, defined } \\
\text { as FIC code equals "USA" and where the Stock Exchange Code } \\
\text { (EXCHG) equals } 11,12,13,14,15,16,17 \text { or } 18 \text {, and zero otherwise. }\end{array}$ \\
\hline RESTRUCTURE & $\begin{array}{l}\text { An indicator variable that equals one if a firm is involved in a } \\
\text { restructuring in the prior three years, and zero otherwise. }\end{array}$ \\
\hline GROWTH & The average of annual sale growth rate in the prior three years. \\
\hline$\% L O S S$ & $\begin{array}{l}\text { The proportion of the current and prior two (minimum) to four } \\
\text { (maximum) years that a firm reports negative earnings }(n i) \text {. }\end{array}$ \\
\hline INVENTORY & Inventory (invt) divided by total assets (at) at the beginning of year t. \\
\hline INT_INTENSITY & $\begin{array}{l}\text { Intangible asset intensity measured by the ratio of the sum of } \\
\text { advertising }(x a d) \text { and research and development expenses }(x r d) \text { to sales } \\
\text { (sale). }\end{array}$ \\
\hline NO_INTENSITY & $\begin{array}{l}\text { An indicator variable that equals one if a firm has no intangible assets, } \\
\text { namely Int_intensity }=0 \text {, and zero otherwise. }\end{array}$ \\
\hline CAP_INTENSITY & $\begin{array}{l}\text { Capital asset intensity measured by the ratio of PPE (ppent) to asset } \\
\text { (at). }\end{array}$ \\
\hline SIZE & $\begin{array}{l}\text { The natural log of total assets (Compustat item at) at the beginning of } \\
\text { year t. }\end{array}$ \\
\hline$B M$ & $\begin{array}{l}\text { The ratio of book value of equity (ceq) to market value of equity } \\
\left(\operatorname{prcc} f^{*} c s h o\right) \text {. }\end{array}$ \\
\hline ZSCORE & $\begin{array}{l}\text { Altman's }(1980) \text { Z-score measured by the following formula: } \\
0.012 *(\text { wcap/at })+0.014^{*}(\text { relat })+0.033(\text { ebit/at })+0.06^{*}\left(\text { prcc } f^{*} \text { csho }\right) /(\text { dltt } \\
+ \text { dlc })+0.999 \text { (salelat }) \text {. }\end{array}$ \\
\hline WRITE-OFF & $\begin{array}{l}\text { An indicator variable that equals one if a firm reports a writedown } \\
(w d p) \text { in the year, and zero otherwise. }\end{array}$ \\
\hline
\end{tabular}




\begin{tabular}{|c|c|}
\hline Variables & Definitions \\
\hline Panel A: & Accruals Analysis \\
\hline AUDITOR & $\begin{array}{l}\text { An indicator variable that equals one if a firm's auditor }(a u) \text { is one of } \\
\text { the largest six audit firms. }\end{array}$ \\
\hline$S T D \_C F O$ & $\begin{array}{l}\text { The standard deviation of cash flow from operations (oancf) divided by } \\
\text { total assets, where the standard deviation is calculated by using the } \\
\text { prior five fiscal years and requiring a minimum of three years of data. }\end{array}$ \\
\hline$S T D \_S A L E$ & $\begin{array}{l}\text { The standard deviation of sales (sale) divided by total assets }(a t) \text {, where } \\
\text { the standard deviation is calculated by using the prior five fiscal years } \\
\text { and requiring a minimum of three years of data. }\end{array}$ \\
\hline$M \& A$ & $\begin{array}{l}\text { An indicator variable that equals one if a firm is involved in a merger or } \\
\text { acquisition in the prior three years, and zero otherwise. }\end{array}$ \\
\hline Panel B: & ICW Analysis \\
\hline$I C W$ & $\begin{array}{l}\text { An indicator variable that equals one if a firm has an ICW reported in } \\
\text { Audit Analytics during the fiscal year and zero otherwise. }\end{array}$ \\
\hline POST & $\begin{array}{l}\text { An indicator variable that equals one if a firm-year's fiscal end falls } \\
\text { between Jan 1, } 2010 \text { and Dec } 31,2014 \text {, and zero otherwise. }\end{array}$ \\
\hline MARKETCAP & $\begin{array}{l}\text { The log of the product of number of shares outstanding (Compustat } \\
\text { item } c s h o \text { ) and share price }(\operatorname{prcc} f) \text {. }\end{array}$ \\
\hline FIRM AGE & The number of years the firm has CRSP pricing data. \\
\hline $\begin{array}{l}\text { AGGREGATE } \\
\text { LOSS }\end{array}$ & $\begin{array}{l}\text { An indicator variable that equals one if the sum of earnings before } \\
\text { extraordinary items }(i b) \text { in year } t \text { and } t-1 \text { is less than zero, and zero } \\
\text { otherwise. }\end{array}$ \\
\hline SEGMENTS & $\begin{array}{l}\text { The sum of the number of operating (Compustat Segment item opseg) } \\
\text { and geographic (geoseg) segments. }\end{array}$ \\
\hline $\begin{array}{l}\text { FOREIGN } \\
\text { TRANSACTIONS }\end{array}$ & $\begin{array}{l}\text { An indicator variable that equals one if the foreign exchange } \\
\text { income/loss }(f c a) \text { is non-zero in year } t \text {, and zero otherwise. }\end{array}$ \\
\hline $\begin{array}{l}\text { ACQUISITION } \\
\text { VALUE }\end{array}$ & $\begin{array}{l}\text { The sum of acquisition }(a q c) \text { in year } \mathrm{t} \text { and } \mathrm{t}-1 \text { scaled by the acquiring } \\
\text { firm's market capitalization. }\end{array}$ \\
\hline $\begin{array}{l}\text { EXTREME SALES } \\
\text { GROWTH }\end{array}$ & $\begin{array}{l}\text { An indicator variable that equals one if industry-adjusted sales growth } \\
\text { from year t- } 1 \text { to } t \text { falls into the top quantile, and zero otherwise. }\end{array}$ \\
\hline RESTRUCTURE & $\begin{array}{l}\text { An indicator variable that equals one if a firm is involved in a } \\
\text { restructuring in year } t \text {, and zero otherwise. }\end{array}$ \\
\hline
\end{tabular}


TABLE 1

Sample Selection

\begin{tabular}{|c|c|c|c|c|}
\hline \multirow[t]{2}{*}{ Sample Selection Criteria } & \multicolumn{4}{|c|}{ Sample Size in Firm-Years } \\
\hline & $\begin{array}{l}\text { Accruals } \\
\text { Analysis- } \\
\text { U.S } \\
\end{array}$ & $\begin{array}{l}\text { Accruals } \\
\text { Analysis- } \\
\text { Canada } \\
\end{array}$ & $\begin{array}{l}\text { Section } \\
404 \text { ICW } \\
\text { Analysis } \\
\end{array}$ & $\begin{array}{l}\text { Section } \\
302 \text { ICW } \\
\text { Analysis } \\
\end{array}$ \\
\hline $\begin{array}{l}\text { All firm-years on Annual Compustat } \\
\text { (North America) with data between Jan } \\
1^{\text {st }}, 2006 \text { and Dec } 31^{\text {st }}, 2015\end{array}$ & 86,171 & 86,171 & 86,171 & 86,171 \\
\hline $\begin{array}{l}\text { Excluding foreign firms and firms in the } \\
\text { financial industry }\end{array}$ & 32,458 & & 32,458 & 32,458 \\
\hline $\begin{array}{l}\text { Excluding U.S. firms, Canadian firms } \\
\text { cross-listed in the U.S., and firms in the } \\
\text { financial industry }\end{array}$ & & 6,802 & & \\
\hline $\begin{array}{l}\text { Excluding firms with missing data for the } \\
\text { regression variables, with total assets less } \\
\text { than or equal to zero, firms belonging to a } \\
\text { two-digit industry SIC group with fewer } \\
\text { than } 20 \text { observations, and/or firms outside } \\
\text { of the sample period } 2006 \text { to } 2014\end{array}$ & 10,138 & 1,488 & & \\
\hline $\begin{array}{l}\text { Excluding firms with missing Section } 302 \\
\text { ICW data from Audit Analytics and/or } \\
\text { missing data for the regression variables }\end{array}$ & & & 19,611 & \\
\hline $\begin{array}{l}\text { Excluding firms with missing Section } 404 \\
\text { ICW data from Audit Analytics and/or } \\
\text { missing data for the regression variables }\end{array}$ & & & & 21,260 \\
\hline
\end{tabular}

${ }^{\text {a }}$ We eliminate all financial sector firms from our sample by excluding all firms with SIC codes in the 6000-6999 range. To focus our analysis on US firms, we select firms where the FIC code equals "USA" and where the Stock Exchange Code (EXCHG) equals 11, 12, 13, 14, 15, 16, 17 or 18.

To identify Canadian firms, we combine firms' CUSIP in Canadian Financial Market Research Centre with firms' CUSIP in Compustat, and require that the FIC code equals "CAN" and the EXCHG equals 7, 8, 9, or 19. 
TABLE 2

Descriptive Statistics

\begin{tabular}{|c|c|c|c|c|c|c|}
\hline \multicolumn{7}{|l|}{ Panel A: US Firms } \\
\hline Variable & $\mathbf{N}$ & $\begin{array}{c}25^{\text {th }} \\
\text { Percentile }\end{array}$ & Mean & Median & $\begin{array}{c}7^{\text {th }} \\
\text { Percentile }\end{array}$ & $\begin{array}{l}\text { Standard } \\
\text { Deviation }\end{array}$ \\
\hline$A B S \_D A$ & 10,138 & 0.014 & 0.051 & 0.032 & 0.064 & 0.059 \\
\hline POST & 10,138 & 0 & 0.532 & 1 & 1 & 0.499 \\
\hline RESTRUCTURE & 10,138 & 0 & 0.495 & 0 & 1 & 0.500 \\
\hline GROWTH & 10,138 & 0.013 & 0.124 & 0.077 & 0.171 & 0.223 \\
\hline$\%$ LOSS & 10,138 & 0 & 0.276 & 0.2 & 0.4 & 0.341 \\
\hline INVENTORY & 10,138 & 0.011 & 0.116 & 0.078 & 0.177 & 0.128 \\
\hline INT_INTENSITY & 10,138 & 0 & 0.163 & 0.018 & 0.072 & 0.725 \\
\hline NO_INTENSITY & 10,138 & 0 & 0.295 & 0 & 1 & 0.456 \\
\hline CA $\bar{P}$ INTENSITY & 10,138 & 0.091 & 0.266 & 0.184 & 0.385 & 0.229 \\
\hline$S I Z E$ & 10,138 & 5.148 & 6.714 & 6.761 & 8.260 & 2.137 \\
\hline$B M$ & 10,138 & 0.256 & 0.540 & 0.461 & 0.734 & 0.554 \\
\hline ZSCORE & 10,138 & 0.606 & 1.612 & 0.988 & 1.541 & 2.774 \\
\hline WRITE-OFF & 10,138 & 0 & 0.177 & 0 & 0 & 0.381 \\
\hline AUDITOR & 10,138 & 1 & 0.847 & 1 & 1 & 0.360 \\
\hline$S T D \_C F O$ & 10,138 & 0.021 & 0.054 & 0.035 & 0.061 & 0.060 \\
\hline$S T D \_S A L E$ & 10,138 & 0.074 & 0.183 & 0.134 & 0.232 & 0.167 \\
\hline$M \& \bar{A}$ & 10,138 & 0 & 0.680 & 1 & 1 & 0.467 \\
\hline \multicolumn{7}{|c|}{ Panel B: Canadian Firms } \\
\hline$A B S \_D A$ & 1,488 & 0.020 & 0.078 & 0.049 & 0.094 & 0.098 \\
\hline POST & 1,488 & 0 & 0.538 & 1 & 1 & 0.499 \\
\hline RESTRUCTURE & 1,488 & 0 & 0.217 & 0 & 0 & 0.412 \\
\hline GROWTH & 1,488 & 0.036 & 0.456 & 0.164 & 0.394 & 1.115 \\
\hline$\% \operatorname{LOSS}$ & 1,488 & 0 & 0.418 & 0.4 & 0.8 & 0.365 \\
\hline INVENTORY & 1,488 & 0 & 0.071 & 0.020 & 0.097 & 0.109 \\
\hline INT_INTENSITY & 1,488 & 0 & 0.044 & 0 & 0 & 0.216 \\
\hline NO_INTENSITY & 1,488 & 1 & 0.817 & 1 & 1 & 0.387 \\
\hline CA $\bar{P}$ INTENSITY & 1,488 & 0.260 & 0.546 & 0.599 & 0.821 & 0.304 \\
\hline$S I Z E^{-}$ & 1,488 & 4.046 & 5.424 & 5.475 & 6.727 & 1.807 \\
\hline$B M$ & 1,488 & 0.398 & 1.034 & 0.692 & 1.201 & 1.594 \\
\hline ZSCORE & 1,488 & 0.273 & 0.979 & 0.527 & 1.109 & 1.515 \\
\hline WRITE-OFF & 1,488 & 0 & 0 & 0 & 0 & 0 \\
\hline AUDITOR & 1,488 & 1 & 0.910 & 1 & 1 & 0.286 \\
\hline$S T D C F O$ & 1,488 & 0.028 & 0.082 & 0.049 & 0.086 & 0.112 \\
\hline STD_SALE & 1,488 & 0.059 & 0.176 & 0.107 & 0.210 & 0.227 \\
\hline$M \& \bar{A}$ & 1,488 & 0 & 0.549 & 1 & 1 & 0.498 \\
\hline
\end{tabular}

This table reports the number of observations $(\mathrm{N}), 25^{\text {th }}$ percentile, mean, median, $75^{\text {th }}$ percentile, and standard deviation for variables used in the main regressions. See the Appendix, Panel A, for variable definitions. All continuous variables are winsorized at the $1 \%$ and $99 \%$ percentiles. 
TABLE 3

The SEC WB Program and Abnormal Accruals

\begin{tabular}{|c|c|c|c|c|c|c|}
\hline & $A B S \_D A$ & $P O S \_D A$ & $N E G_{-} D A$ & $A B S \_D A$ & $P O S \_D A$ & $N E G \_D A$ \\
\hline \multirow[t]{2}{*}{ Intercept } & $0.070 * * *$ & $0.065 * * *$ & $-0.075 * * *$ & $0.070 * * *$ & $0.065 * * *$ & $-0.076 * * *$ \\
\hline & $(0.000)$ & $(0.000)$ & $(0.000)$ & $(0.000)$ & $(0.000)$ & $(0.000)$ \\
\hline \multirow[t]{2}{*}{ POST } & $-0.008 * * *$ & $-0.006 * * *$ & $0.013 * * *$ & $-0.009 * * *$ & $-0.006 * * *$ & $0.014 * * *$ \\
\hline & $(0.000)$ & $(0.000)$ & $(0.000)$ & $(0.000)$ & $(0.000)$ & $(0.000)$ \\
\hline \multirow[t]{2}{*}{ QUI TAM } & & & & -0.004 & 0.002 & 0.010 \\
\hline & & & & $(0.248)$ & $(0.509)$ & $(0.118)$ \\
\hline \multirow[t]{2}{*}{$P O S T^{*} Q U I T A M$} & & & & 0.006 & -0.001 & $-0.015^{*}$ \\
\hline & & & & $(0.175)$ & $(0.888)$ & $(0.076)$ \\
\hline \multirow[t]{2}{*}{ RESTRUCTURE } & $0.031 * * *$ & $0.015 * * *$ & $-0.042 * * *$ & $-0.002 *$ & -0.001 & 0.003 \\
\hline & $(0.000)$ & $(0.000)$ & $(0.000)$ & $(0.096)$ & $(0.586)$ & $(0.173)$ \\
\hline \multirow[t]{2}{*}{ GROWTH } & $-0.028 * * *$ & $-0.014 * *$ & $0.049 * * *$ & $0.014 * * *$ & $0.011 * *$ & $-0.016 * * *$ \\
\hline & $(0.000)$ & $(0.028)$ & $(0.000)$ & $(0.000)$ & $(0.019)$ & $(0.005)$ \\
\hline \multirow[t]{2}{*}{$\% L O S S$} & $0.031 * * *$ & $0.015 * * *$ & $-0.042 * * *$ & $0.031 * * *$ & $0.015 * * *$ & $-0.042 * * *$ \\
\hline & $(0.000)$ & $(0.000)$ & $(0.000)$ & $(0.000)$ & $(0.000)$ & $(0.000)$ \\
\hline \multirow[t]{2}{*}{ INVENTORY } & $-0.028 * * *$ & $-0.014 * *$ & $0.049 * * *$ & $-0.028 * * *$ & $-0.013 * *$ & $0.050 * * *$ \\
\hline & $(0.000)$ & $(0.028)$ & $(0.000)$ & $(0.000)$ & $(0.038)$ & $(0.000)$ \\
\hline \multirow[t]{2}{*}{ INT_INTENSITY } & $0.003 * *$ & 0.001 & $-0.010 * * *$ & $0.004 * *$ & 0.001 & $-0.010 * * *$ \\
\hline & $(0.049)$ & $(0.512)$ & $(0.002)$ & $(0.049)$ & $(0.505)$ & $(0.002)$ \\
\hline \multirow[t]{2}{*}{ NO_INTENSITY } & $-0.004 * *$ & $-0.004 * *$ & 0.004 & $-0.004 * *$ & $-0.004 * *$ & 0.004 \\
\hline & $(0.013)$ & $(0.028)$ & $(0.111)$ & $(0.015)$ & $(0.022)$ & $(0.129)$ \\
\hline \multirow[t]{2}{*}{ CAP_INTENSITY } & $-0.022 * * *$ & $-0.026 * * *$ & $0.018 * * *$ & $-0.022 * * *$ & $-0.026 * * *$ & $0.019 * * *$ \\
\hline & $(0.000)$ & $(0.000)$ & $(0.003)$ & $(0.000)$ & $(0.000)$ & $(0.002)$ \\
\hline \multirow[t]{2}{*}{ SIZE } & $-0.003 * * *$ & $-0.002 * * *$ & $0.004 * * *$ & $-0.003 * * *$ & $-0.002 * * *$ & $0.004 * * *$ \\
\hline & $(0.000)$ & $(0.000)$ & $(0.000)$ & $(0.000)$ & $(0.000)$ & $(0.000)$ \\
\hline \multirow[t]{2}{*}{$B M$} & -0.002 & -0.000 & 0.001 & -0.002 & -0.000 & 0.002 \\
\hline & $(0.176)$ & $(0.825)$ & $(0.478)$ & $(0.171)$ & $(0.832)$ & $(0.457)$ \\
\hline \multirow[t]{2}{*}{ ZSCORE } & $-0.001 * * *$ & -0.000 & $0.001 * * *$ & $-0.001 * * *$ & -0.000 & $0.001 * * *$ \\
\hline & $(0.001)$ & $(0.304)$ & $(0.000)$ & $(0.001)$ & $(0.309)$ & $(0.000)$ \\
\hline \multirow[t]{2}{*}{ WRITE-OFF } & $0.012 * * *$ & 0.000 & $-0.021 * * *$ & $0.012 * * *$ & 0.000 & $-0.021 * * *$ \\
\hline & $(0.000)$ & $(0.913)$ & $(0.000)$ & $(0.000)$ & $(0.928)$ & $(0.000)$ \\
\hline \multirow[t]{2}{*}{$A U D I T O R$} & $-0.006^{* *}$ & $-0.006 * *$ & 0.006 & $-0.006^{* *}$ & $-0.006 * *$ & 0.006 \\
\hline & $(0.017)$ & $(0.038)$ & $(0.158)$ & $(0.017)$ & (0.039) & $(0.152)$ \\
\hline
\end{tabular}




\begin{tabular}{|c|c|c|c|c|c|c|}
\hline$S T D \_C F O$ & $\begin{array}{l}0.168 * * * \\
(0.000)\end{array}$ & $\begin{array}{l}0.193 * * * \\
(0.000)\end{array}$ & $\begin{array}{l}-0.156^{* * *} \\
(0.000)\end{array}$ & $\begin{array}{l}0.006 \\
(0.270)\end{array}$ & $\begin{array}{l}0.002 \\
(0.799)\end{array}$ & $\begin{array}{l}-0.009 \\
(0.259)\end{array}$ \\
\hline STD_SALE & $\begin{array}{l}0.006 \\
(0.279)\end{array}$ & $\begin{array}{l}0.002 \\
(0.754)\end{array}$ & $\begin{array}{l}-0.009 \\
(0.295)\end{array}$ & $\begin{array}{l}0.168 * * * \\
(0.000)\end{array}$ & $\begin{array}{l}0.193 * * * \\
(0.000)\end{array}$ & $\begin{array}{l}-0.155^{* * *} \\
(0.000)\end{array}$ \\
\hline$M \& A$ & $\begin{array}{l}-0.001 \\
(0.697)\end{array}$ & $\begin{array}{l}-0.005^{* * *} \\
(0.002)\end{array}$ & $\begin{array}{l}-0.004 \\
(0.133)\end{array}$ & $\begin{array}{l}-0.001 \\
(0.696)\end{array}$ & $\begin{array}{l}-0.005^{* * *} \\
(0.002)\end{array}$ & $\begin{array}{l}-0.004 \\
(0.142)\end{array}$ \\
\hline $\begin{array}{l}\text { Sum of the coefficients } \\
P O S T+P O S T^{*} Q U I T A M\end{array}$ & & & & $\begin{array}{l}-0.003 \\
(0.589)\end{array}$ & $\begin{array}{l}-0.007 \\
(0.110)\end{array}$ & $\begin{array}{l}-0.001 \\
(0.878)\end{array}$ \\
\hline Cluster by firm & Yes & Yes & Yes & Yes & Yes & Yes \\
\hline F-value $(\operatorname{Pr}>F)$ & $\begin{array}{l}64.67 \\
(0.0000)\end{array}$ & $\begin{array}{l}34.09 \\
(0.0000)\end{array}$ & $\begin{array}{l}39.27 \\
(0.0000)\end{array}$ & $\begin{array}{l}57.63 \\
(0.0000)\end{array}$ & $\begin{array}{l}30.57 \\
(0.0000)\end{array}$ & $\begin{array}{l}35.23 \\
(0.0000)\end{array}$ \\
\hline Number & 10,138 & 5,722 & 4,416 & 10,138 & 5,722 & 4,416 \\
\hline
\end{tabular}

The table presents the Tobit regression results on the effect of Whistleblower Provisions on abnormal accruals. The dependent variable is the absolute value of abnormal accruals $\left(A B S \_D A\right)$ estimated by using the cross-sectional McNichols (2002) model. In column 2, the dependent variable is the value of positive abnormal accruals (POS_DA) using the cross-sectional McNichols (2002) model; in column 3, the dependent variable is the value of negative abnormal accruals $\left(N E G_{-} D A\right)$. The sample includes all available firm-year observations from 2006 to 2014 in all columns. $P$-value based on standard errors clustered by firm is displayed in parentheses. See the Appendix, Panel A, for variable definitions. All continuous variables are winsorized at the $1 \%$ and $99 \%$ percentiles. ${ }^{* * *},{ }^{* *}$, and ${ }^{*}$ indicate significance at the $1 \%, 5 \%$, and $10 \%$ levels, respectively, for two-tailed tests. 
TABLE 4

The SEC WB Program and Abnormal Accruals - US versus Canadian Firms

\begin{tabular}{|c|c|c|c|}
\hline & $A B S \_D A$ & POS_DA & $N E G \_D A$ \\
\hline \multirow[t]{2}{*}{ Intercept } & $0.081 * * *$ & $0.08 \overline{3} * * *$ & $-0.080 * * *$ \\
\hline & $(0.000)$ & $(0.000)$ & $(0.000)$ \\
\hline \multirow[t]{2}{*}{ POST } & 0.002 & -0.004 & -0.010 \\
\hline & $(0.596)$ & $(0.474)$ & $(0.179)$ \\
\hline \multirow[t]{2}{*}{ TREATMENT } & $-0.014 * * *$ & $-0.020 * * *$ & 0.007 \\
\hline & $(0.000)$ & $(0.000)$ & $(0.274)$ \\
\hline \multirow[t]{2}{*}{ POST ${ }^{*}$ TREATMENT } & $-0.011 * *$ & -0.002 & $0.023 * * *$ \\
\hline & $(0.016)$ & $(0.692)$ & $(0.003)$ \\
\hline \multirow[t]{2}{*}{ RESTRUCTURE } & $-0.003 * *$ & -0.002 & 0.003 \\
\hline & $(0.048)$ & $(0.311)$ & $(0.140)$ \\
\hline \multirow[t]{2}{*}{ GROWTH } & $0.011 * * *$ & $0.010 * *$ & $-0.012 * * *$ \\
\hline & $(0.000)$ & $(0.012)$ & $(0.001)$ \\
\hline \multirow[t]{2}{*}{$\% L O S S$} & $0.030 * * *$ & $0.013 * * *$ & $-0.043 * * *$ \\
\hline & $(0.000)$ & $(0.000)$ & $(0.000)$ \\
\hline \multirow[t]{2}{*}{ INVENTORY } & $-0.026 * * *$ & $-0.013^{*}$ & $0.044 * * *$ \\
\hline & $(0.000)$ & $(0.054)$ & $(0.000)$ \\
\hline \multirow[t]{2}{*}{ INT_INTENSITY } & $0.003 *$ & 0.001 & $-0.009 * * *$ \\
\hline & $(0.084)$ & $(0.664)$ & $(0.002)$ \\
\hline \multirow[t]{2}{*}{ NO_INTENSITY } & $-0.004 * * *$ & $-0.004 * *$ & 0.004 \\
\hline & $(0.010)$ & $(0.017)$ & $(0.136)$ \\
\hline \multirow[t]{2}{*}{ CAP_INTENSITY } & $-0.020 * * *$ & $-0.025^{* * *}$ & $0.016^{* *}$ \\
\hline & $(0.000)$ & $(0.000)$ & $(0.011)$ \\
\hline \multirow[t]{2}{*}{ SIZE } & $-0.003 * * *$ & $-0.002 * * *$ & $0.004 * * *$ \\
\hline & $(0.000)$ & $(0.002)$ & $(0.000)$ \\
\hline \multirow[t]{2}{*}{$B M$} & $-0.002 *$ & -0.001 & 0.002 \\
\hline & $(0.084)$ & $(0.273)$ & $(0.262)$ \\
\hline \multirow[t]{2}{*}{ ZSCORE } & $-0.001 * * *$ & -0.000 & $0.001 * * *$ \\
\hline & $(0.001)$ & $(0.279)$ & $(0.000)$ \\
\hline \multirow[t]{2}{*}{ WRITE-OFF } & $0.012 * * *$ & 0.000 & $-0.021 * * *$ \\
\hline & $(0.000)$ & $(0.846)$ & $(0.000)$ \\
\hline \multirow[t]{2}{*}{ AUDITOR } & $-0.005^{*}$ & $-0.007 * *$ & 0.004 \\
\hline & $(0.063)$ & $(0.033)$ & $(0.363)$ \\
\hline \multirow[t]{2}{*}{ STD_CFO } & $0.190 * * *$ & $0.230 * * *$ & $-0.158 * * *$ \\
\hline & $(0.000)$ & $(0.000)$ & $(0.000)$ \\
\hline \multirow[t]{2}{*}{$S T D \_S A L E$} & 0.006 & 0.002 & -0.010 \\
\hline & $(0.300)$ & $(0.847)$ & $(0.276)$ \\
\hline \multirow[t]{2}{*}{$M \& A$} & -0.000 & $-0.004 * *$ & -0.003 \\
\hline & $(0.776)$ & $(0.011)$ & $(0.250)$ \\
\hline & Yes & Yes & Yes \\
\hline \multirow{2}{*}{ F-value $(\operatorname{Pr}>F)$} & 62.11 & 30.19 & 38.20 \\
\hline & $(0.0000)$ & $(0.0000)$ & $(0.0000)$ \\
\hline Number & 11,626 & 6,530 & 5,096 \\
\hline
\end{tabular}


The table presents the Tobit regression results on the effect of Whistleblower Provisions on abnormal accruals. The dependent variable is the absolute value of abnormal accruals $\left(A B S \_D A\right)$ estimated by using the cross-sectional McNichols (2002) model. In column 2 , the dependent variable is the value of positive abnormal accruals (POS_DA) using the cross-sectional McNichols (2002) model; in column 3, the dependent variable is the value of negative abnormal accruals ( $\left.N E G_{-} D A\right)$. The sample includes all available firm-year observations from 2006 to 2014 in all columns. $P$-value based on standard errors clustered by firm is displayed in parentheses. See the Appendix, Panel A, for variable definitions. All continuous variables are winsorized at the $1 \%$ and $99 \%$ percentiles. ${ }^{* * *},{ }^{* *}$, and ${ }^{*}$ indicate significance at the $1 \%, 5 \%$, and $10 \%$ levels, respectively, for two-tailed tests. 
TABLE 5

The SEC WB Program and Abnormal Accruals - Impact of Firm Internal Compliance Program Strength

\begin{tabular}{|c|c|c|c|c|c|}
\hline \multicolumn{6}{|c|}{$\begin{array}{l}\text { ABS_DA }=\alpha_{0}+\alpha_{1} P O S T+\alpha_{2} W B \_T O T+\alpha_{3} P O S T * W B \_T O T+\alpha_{4} R E S T R U C T U R E+ \\
\alpha_{5} G R O W T H+\alpha_{6} \% L O S S+\alpha_{7} I N V E N T O R Y+\alpha_{8} I N T \_I N T E N S I T Y+\alpha_{9} N O \_I N T+ \\
\alpha_{10} C A P \_I N T E N S I T Y+\alpha_{11} S I Z E+\alpha_{12} B M+\alpha_{13} Z S C O R E+\alpha_{14} W R I T E-O F F+ \\
\alpha_{15} A U D I T O R+\alpha_{16} S T D \_C F O+\alpha_{17} S T D \_S A L E+\alpha_{18} M \& A+\sum I N D U S T R Y+\varepsilon\end{array}$} \\
\hline & & & $B S \_D A$ & & \\
\hline Intercept & $\begin{array}{l}0.034 * * * \\
(0.009)\end{array}$ & $\begin{array}{l}0.039 * * * \\
(0.003)\end{array}$ & $\begin{array}{l}0.038 * * * \\
(0.004)\end{array}$ & $\begin{array}{l}0.032 * * \\
(0.018)\end{array}$ & $\begin{array}{l}0.044 * * * \\
(0.001)\end{array}$ \\
\hline POST & $\begin{array}{l}0.005 \\
(0.342)\end{array}$ & $\begin{array}{l}-0.005 \\
(0.176)\end{array}$ & $\begin{array}{l}0.002 \\
(0.734)\end{array}$ & $\begin{array}{l}0.008 \\
(0.226)\end{array}$ & $\begin{array}{l}-0.005 \\
(0.127)\end{array}$ \\
\hline$W B \_T O T$ & $\begin{array}{l}0.001 \\
(0.124)\end{array}$ & & & & \\
\hline$P O S T^{*} W B \_T O T$ & $\begin{array}{l}-0.002 * * \\
(0.014)\end{array}$ & & & & \\
\hline$W B \_P E$ & & $\begin{array}{l}0.002 \\
(0.507)\end{array}$ & & & \\
\hline$P O S T^{*} W B \_P E$ & & $\begin{array}{l}-0.002 \\
(0.544)\end{array}$ & & & \\
\hline$W B \_I R$ & & & $\begin{array}{l}0.001 \\
(0.377)\end{array}$ & & \\
\hline$P O S T^{*} W B \_I R$ & & & $\begin{array}{l}-0.003 * * \\
(0.046)\end{array}$ & & \\
\hline WB_PROT & & & & $\begin{array}{l}0.002^{*} \\
(0.086)\end{array}$ & \\
\hline POST ${ }^{*} W B \_P R O T$ & & & & $\begin{array}{l}-0.004^{* *} \\
(0.019)\end{array}$ & \\
\hline$L O B B Y$ & & & & & $\begin{array}{l}-0.002 \\
(0.565)\end{array}$ \\
\hline$P O S T^{*} L O B B Y$ & & & & & $\begin{array}{l}-0.004 \\
(0.452)\end{array}$ \\
\hline RESTRUCTURE & $\begin{array}{l}-0.001 \\
(0.861)\end{array}$ & $\begin{array}{l}-0.000 \\
(0.902)\end{array}$ & $\begin{array}{l}-0.001 \\
(0.775)\end{array}$ & $\begin{array}{l}-0.000 \\
(0.903)\end{array}$ & $\begin{array}{l}-0.000 \\
(0.920)\end{array}$ \\
\hline GROWTH & $\begin{array}{l}0.024 * * \\
(0.022)\end{array}$ & $\begin{array}{l}0.024 * * \\
(0.019)\end{array}$ & $\begin{array}{l}0.023 * * \\
(0.029)\end{array}$ & $\begin{array}{l}0.024 * * \\
(0.020)\end{array}$ & $\begin{array}{l}0.023 * * \\
(0.028)\end{array}$ \\
\hline$\% \operatorname{LOSS}$ & $\begin{array}{l}0.028 * * * \\
(0.000)\end{array}$ & $\begin{array}{l}0.028 * * * \\
(0.000)\end{array}$ & $\begin{array}{l}0.028 * * * \\
(0.000)\end{array}$ & $\begin{array}{l}0.028 * * * \\
(0.000)\end{array}$ & $\begin{array}{l}0.027 * * * \\
(0.000)\end{array}$ \\
\hline INVENTORY & $\begin{array}{l}-0.006 \\
(0.728)\end{array}$ & $\begin{array}{l}-0.006 \\
(0.722)\end{array}$ & $\begin{array}{l}-0.006 \\
(0.738)\end{array}$ & $\begin{array}{l}-0.006 \\
(0.734)\end{array}$ & $\begin{array}{l}-0.008 \\
(0.621)\end{array}$ \\
\hline INT_INTENSITY & $\begin{array}{l}0.006 \\
(0.795)\end{array}$ & $\begin{array}{l}0.007 \\
(0.769)\end{array}$ & $\begin{array}{l}0.006 \\
(0.781)\end{array}$ & $\begin{array}{l}0.006 \\
(0.780)\end{array}$ & $\begin{array}{l}0.006 \\
(0.777)\end{array}$ \\
\hline NO_INTENSITY & $\begin{array}{l}-0.010^{* * * *} \\
(0.001)\end{array}$ & $\begin{array}{l}-0.010^{* * * *} \\
(0.001)\end{array}$ & $\begin{array}{l}-0.010^{* * *} \\
(0.001)\end{array}$ & $\begin{array}{l}-0.010^{* * *} \\
(0.001)\end{array}$ & $\begin{array}{l}-0.011 * * * \\
(0.000)\end{array}$ \\
\hline CAP_INTENSITY & $\begin{array}{l}-0.012 \\
(0.110)\end{array}$ & $\begin{array}{l}-0.012 \\
(0.114)\end{array}$ & $\begin{array}{l}-0.012 \\
(0.106)\end{array}$ & $\begin{array}{l}-0.011 \\
(0.116)\end{array}$ & $\begin{array}{l}-0.012 \\
(0.114)\end{array}$ \\
\hline SIZE & $\begin{array}{l}-0.001 \\
(0.153)\end{array}$ & $\begin{array}{l}-0.001 \\
(0.142)\end{array}$ & $\begin{array}{l}-0.001 \\
(0.132)\end{array}$ & $\begin{array}{l}-0.001 \\
(0.159)\end{array}$ & $\begin{array}{l}-0.001 \\
(0.116)\end{array}$ \\
\hline
\end{tabular}




\begin{tabular}{llllll} 
BM & 0.002 & 0.002 & 0.002 & 0.002 & 0.003 \\
ZSCORE & $(0.579)$ & $(0.579)$ & $(0.551)$ & $(0.628)$ & $(0.490)$ \\
& -0.001 & -0.000 & -0.000 & -0.001 & -0.000 \\
WRITEOFF & $(0.499)$ & $(0.565)$ & $(0.531)$ & $(0.509)$ & $(0.572)$ \\
& 0.004 & 0.004 & 0.004 & 0.004 & 0.004 \\
AUDITOR & $(0.172)$ & $(0.166)$ & $(0.177)$ & $(0.167)$ & $(0.217)$ \\
& 0.001 & 0.001 & 0.001 & 0.001 & 0.000 \\
STD_CFO & $(0.933)$ & $(0.900)$ & $(0.928)$ & $(0.938)$ & $(0.967)$ \\
& 0.002 & 0.002 & 0.001 & 0.002 & 0.001 \\
STD_SALE & $(0.885)$ & $(0.920)$ & $(0.937)$ & $(0.906)$ & $(0.928)$ \\
& $0.241 * * *$ & $0.236 * * *$ & $0.237 * * *$ & $0.241 * * *$ & $0.239^{* * *}$ \\
M\&A & $(0.000)$ & $(0.000)$ & $(0.000)$ & $(0.000)$ & $(0.000)$ \\
& 0.003 & 0.002 & 0.003 & 0.002 & 0.002 \\
Intercept & $(0.419)$ & $(0.514)$ & $(0.402)$ & $(0.487)$ & $(0.441)$ \\
& $0.034 * * *$ & $0.039 * * *$ & $0.038^{* * *}$ & $0.032 * *$ & $0.044 * * *$ \\
& $(0.009)$ & $(0.003)$ & $(0.004)$ & $(0.018)$ & $(0.001)$ \\
Cluster by firm & & & & & \\
F-value (Pr>F) & 12.19 & 12.38 & 12.04 & 12.23 & 12.27 \\
& $(0.0000)$ & $(0.0000)$ & $(0.0000)$ & $(0.0000)$ & $(0.0000)$ \\
Number & 1,502 & 1,502 & 1,502 & 1,502 & 1,502 \\
\hline
\end{tabular}

The table shows the Tobit regression results on the impact of weak internal reporting on the negative relation between Whistleblower Provisions and absolute abnormal accruals. Following BMW (2017), we use four proxies for weak internal reporting: $W B \_P E$ (i.e., the score of program efficacy), $W B \_I R$ (i.e., the score of independence of reporting), WB_PROT (i.e., the score of the protection of Whistleblowers), and $W B \_T O T$ (i.e., the sum of the three scores). The sample includes all available firmyear observations from 2006 to 2014 in all columns. $P$-value based on standard errors clustered by firm is displayed in parentheses. See the Appendix, Panel A, for variable definitions. All continuous variables are winsorized at the 1\% and $99 \%$ percentiles. ${ }^{* * *},{ }^{* *}$, and ${ }^{*}$ indicate significance at the $1 \%, 5 \%$, and $10 \%$ levels, respectively, for twotailed tests. 
TABLE 6

Descriptive Statistics - Section 404 and 302 Internal Control Weakness

Analysis

\begin{tabular}{|c|c|c|c|c|c|c|}
\hline \multicolumn{7}{|c|}{ Panel A: Section 404} \\
\hline Variable & $\mathbf{N}$ & $\begin{array}{c}2^{\text {th }} \\
\text { Percentile }\end{array}$ & Mean & Median & $\begin{array}{c}7^{\text {th }} \\
\text { Percentile }\end{array}$ & $\begin{array}{l}\text { Standard } \\
\text { Deviation }\end{array}$ \\
\hline$I C W$ & 19,611 & 0 & 0.061 & 0 & 0 & 0.240 \\
\hline POST & 19,611 & 0 & 0.558 & 1 & 1 & 0.497 \\
\hline MARKETCAP & 19,611 & 5.132 & 6.467 & 6.445 & 7.787 & 1.959 \\
\hline FIRM AGE & 19,611 & 7.578 & 19.815 & 14.816 & 25.734 & 17.603 \\
\hline $\begin{array}{l}\text { AGGREGATE } \\
\text { LOSS }\end{array}$ & 19,611 & 0 & 0.310 & 0 & 1 & 0.462 \\
\hline SEGMENTS & 19,611 & 1 & 3.247 & 2 & 5 & 3.398 \\
\hline $\begin{array}{l}\text { FOREIGN } \\
\text { TRANSACTIONS }\end{array}$ & 19,611 & 0 & 0.323 & 0 & 1 & 0.468 \\
\hline $\begin{array}{l}\text { ACQUISITION } \\
\text { VALUE }\end{array}$ & 19,611 & 0 & 0.065 & 0.001 & 0.055 & 0.153 \\
\hline $\begin{array}{l}\text { EXTREME SALES } \\
\text { GROWTH }\end{array}$ & 19,611 & 0 & 0.264 & 0 & 1 & 0.441 \\
\hline RESTRUCTURE & 19,611 & 0 & 0.313 & 0 & 1 & 0.464 \\
\hline \multicolumn{7}{|c|}{ Panel B: Section 302} \\
\hline Variable & $\mathbf{N}$ & $\begin{array}{c}25^{\text {th }} \\
\text { Percentile }\end{array}$ & Mean & Median & $\begin{array}{c}7^{\text {th }} \\
\text { Percentile }\end{array}$ & $\begin{array}{l}\text { Standard } \\
\text { Deviation }\end{array}$ \\
\hline$I C W$ & 21,260 & 0 & 0.091 & 0 & 0 & 0.288 \\
\hline POST & 21,260 & 0 & 0.556 & 1 & 1 & 0.497 \\
\hline MARKETCAP & 21,260 & 5.451 & 6.730 & 6.641 & 7.926 & 1.808 \\
\hline FIRM AGE & 21,260 & 7.603 & 20.214 & 15.118 & 26.630 & 17.887 \\
\hline $\begin{array}{l}\text { AGGREGATE } \\
\text { LOSS }\end{array}$ & 21,260 & 0 & 0.290 & 0 & 1 & 0.454 \\
\hline SEGMENTS & 21,260 & 1 & 3.297 & 2 & 5 & 3.348 \\
\hline $\begin{array}{l}\text { FOREIGN } \\
\text { TRANSACTIONS }\end{array}$ & 21,260 & 0 & 0.324 & 0 & 1 & 0.468 \\
\hline $\begin{array}{l}\text { ACQUISITION } \\
\text { VALUE }\end{array}$ & 21,260 & 0 & 0.065 & 0.002 & 0.056 & 0.151 \\
\hline $\begin{array}{l}\text { EXTREME SALES } \\
\text { GROWTH }\end{array}$ & 21,260 & 0 & 0.258 & 0 & 1 & 0.438 \\
\hline RESTRUCTURE & 21,260 & 0 & 0.338 & 0 & 1 & 0.473 \\
\hline
\end{tabular}


This table reports the number of observations $(\mathrm{N}), 25^{\text {th }}$ percentile, mean, median, $75^{\text {th }}$ percentile, and standard deviation for variables used in the main regressions. All continuous variables are winsorized at the $1 \%$ and $99 \%$ percentiles. See the Appendix, Panel B, for variable definitions. 
TABLE 7

The SEC WB Program and Section 404 and 302 Internal Controls Weaknesses

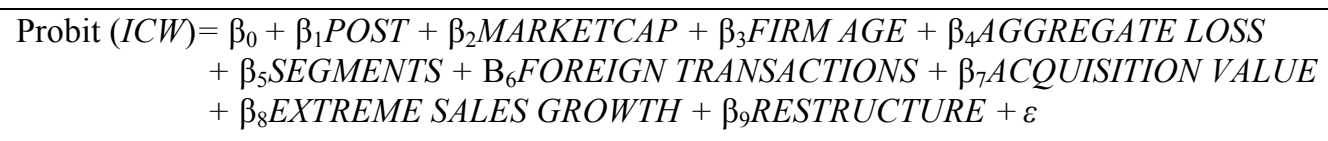

\section{Probit (ICW)}

\begin{tabular}{lll}
\hline & Section 404 & Section 302 \\
\hline Intercept & $-0.698^{* * *}$ & $-0.355^{* * *}$ \\
POST & $(0.000)$ & $(0.000)$ \\
& $-0.093^{* * *}$ & $-0.231^{* * *}$ \\
MARKETCAP & $(0.002)$ & $(0.000)$ \\
& $-0.140^{* * *}$ & $-0.152^{* * *}$ \\
FIRM AGE & $(0.000)$ & $(0.000)$ \\
& $-0.005^{* * *}$ & $-0.005^{* * *}$ \\
AGGREGATE LOSS & $(0.000)$ & $(0.000)$ \\
& $0.085^{* * *}$ & $0.183^{* * *}$ \\
SEGMENTS & $(0.009)$ & $(0.000)$ \\
FOREIGN & $0.009^{*}$ & $0.014^{* * *}$ \\
TRANSACTIONS & $(0.056)$ & $(0.001)$ \\
ACQUISITION VALUE & 0.046 & $0.127^{* * *}$ \\
& $(0.167)$ & $(0.000)$ \\
EXTREME SALES & 0.055 & -0.058 \\
GROWTH & $(0.527)$ & $(0.457)$ \\
RESTRUCTURE & $0.139^{* * *}$ & $0.097^{* * *}$ \\
& $(0.000)$ & $(0.001)$ \\
Pseudo R-squared & 0.050 & 0.043 \\
Number & $(0.140)$ & $(0.131)$ \\
\hline
\end{tabular}

This table presents the Probit regression results on the effect of the SEC Whistleblower Provisions on internal control. The dependent variable in column 1 (2), $I C W$, is an indicator variable equal to one if a firm has an internal control weakness reported in Audit Analytics Section 404 (Section 302) during the fiscal year (any quarter during the fiscal year) and zero otherwise. The sample includes all available firm-year observations from 2006 to 2014 in all columns. $P$-value based on standard errors clustered by firm is displayed in parentheses. See the Appendix, Panel B for variable definitions. ${ }^{* * *},{ }^{* *}$, and ${ }^{*}$ indicate significance at the $1 \%, 5 \%$, and $10 \%$ levels, respectively, for two-tailed tests. 
TABLE 8

Ineffective Control Disclosures Under Section 302 - Internal Compliance Programs

\begin{tabular}{|c|c|c|c|c|c|c|c|c|c|c|c|}
\hline & 2006 & 2007 & 2008 & 2009 & 2010 & 2011 & 2012 & 2013 & 2014 & $\begin{array}{l}\text { Average } \\
P R E \\
\text { 2006-2009 }\end{array}$ & $\begin{array}{l}\text { Average } \\
\text { POST } \\
\text { 2010-2014 } \\
\end{array}$ \\
\hline \multicolumn{12}{|c|}{ Panel A - Code 82 - Inadequate or not-implemented internal whistleblower policy (including a hotline) } \\
\hline Frequency & $0.61 \%$ & $0.76 \%$ & $0.65 \%$ & $0.52 \%$ & $0.51 \%$ & $0.33 \%$ & $0.30 \%$ & $0.25 \%$ & $0.33 \%$ & $0.64 \%$ & $0.34 \%$ \\
\hline Number & 44 & 53 & 43 & 33 & 32 & 21 & 19 & 16 & 21 & 43.3 & 21.8 \\
\hline \multicolumn{12}{|c|}{ Panel B - Code 84 - Problem involving the formulation or implementation of an effective Code of Ethics } \\
\hline Frequency & $0.80 \%$ & $1.28 \%$ & $1.10 \%$ & $0.96 \%$ & $0.98 \%$ & $0.70 \%$ & $0.59 \%$ & $0.40 \%$ & $0.56 \%$ & $1.04 \%$ & $0.65 \%$ \\
\hline Number & 57 & 89 & 72 & 61 & 62 & 44 & 37 & 25 & 35 & 69.8 & 40.6 \\
\hline \multicolumn{12}{|c|}{ Panel C - Code 67 - Weakness relating to the senior management tone ("tone at the top") } \\
\hline Frequency & $1.70 \%$ & $1.89 \%$ & $1.58 \%$ & $1.04 \%$ & $0.82 \%$ & $0.40 \%$ & $0.32 \%$ & $0.32 \%$ & $0.19 \%$ & $1.55 \%$ & $0.41 \%$ \\
\hline Number & 122 & 132 & 104 & 66 & 52 & 25 & 20 & 20 & 12 & 106.0 & 25.8 \\
\hline
\end{tabular}

The table reports the frequency of weaknesses relating to a firm's internal whistleblower policy and / or Code of Ethics. A firm is included in the count if the code appears in any of four quarters in the fiscal year. 
TABLE 9

The SEC WB Program and ICWs relating to a Firm's Internal Compliance Program

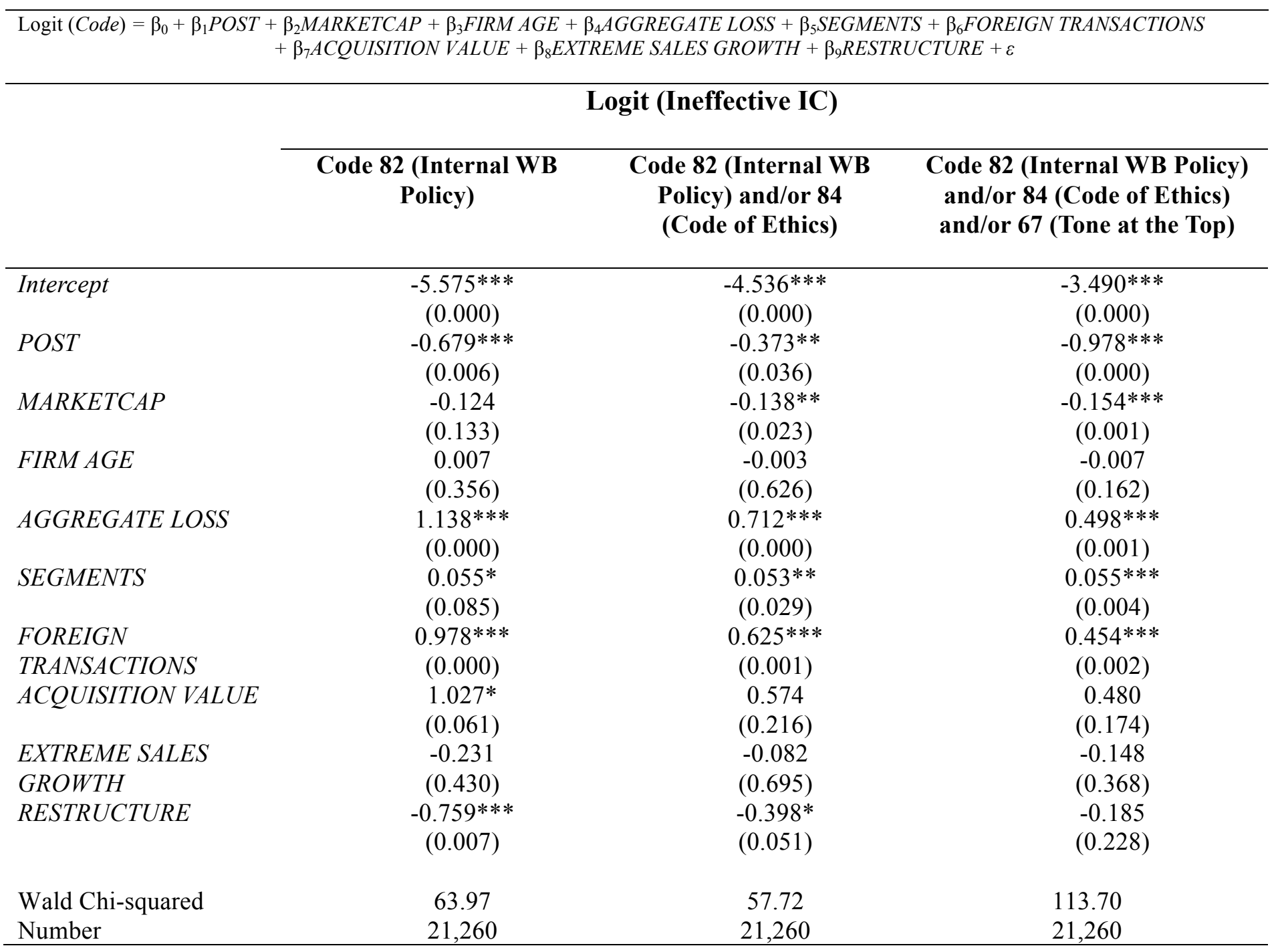


This table presents the Logit regression results of the effect of the SEC Whistleblower Provisions on internal control weaknesses related to a firm's internal compliance program using Penalized Maximum Likelihood Estimation. The dependent variable in column 1 is a weakness is the firm's internal WB Policy (Code 82) and is equal to one if the code appears in any of four quarters in the fiscal year, or zero otherwise. The dependent variable in column 2 is a weakness is the firm's internal WB Policy (Code 82) and/or Code of Ethics (Code 84) and is equal to one if the code appears in either category in any of four quarters in the fiscal year, or zero otherwise. The dependent variable in column 3 is a weakness is the firm's internal WB Policy (Code 82) and/or Code of Ethics (Code 84) and/or Tone at the Top (Code 67) and is equal to one if the code appears in either of the three categories in any of four quarters in the fiscal year, or zero otherwise. The sample includes all available firm-year observations from 2006 to 2014 in all columns. $P$-value based on standard errors clustered by firm is displayed in parentheses. See the Appendix, Panel B for variable definitions. ${ }^{* * *},{ }^{* *}$, and ${ }^{*}$ indicate significance at the $1 \%, 5 \%$, and $10 \%$ levels, respectively, for two-tailed tests. 